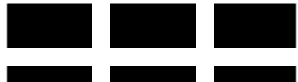 \\ ThE WiLliam DAVIDSON INSTITUTE \\ AT THE UNIVERSITY OF MICHIGAN
}

\section{THE ROLE OF FOREIGN DIRECT INVESTMENT IN THE FIRM SELECTION PROCESS IN A HOST COUNTRY: EVIDENCE FROM SLOVENIA}

\author{
By: Katja Zajc Kejžar
}

William Davidson Institute Working Paper Number 841

September 2006 


\title{
THE ROLE OF FOREIGN DIRECT INVESTMENT IN THE FIRM SELECTION PROCESS IN A HOST COUNTRY: EVIDENCE FROM SLOVENIA
}

\author{
Katja Zajc Kejžar \\ University of Ljubljana, Faculty of Economics, Slovenia
}

September 2006

\begin{abstract}
This paper examines the role of inward foreign direct investment (FDI) in firm selection processes in the Slovenian manufacturing sector in the 1994-2003 period by assessing the impact of the entry and presence of foreign firms on a domestic firm's probability of exiting. The results confirm that not only do foreign entrants tend to be above-average productive but they also find it easier to exit (particularly those entering in the form of acquisitions). Further, the least efficient firms are found to experience a drop in their survival probability upon a foreign firm's entry. In addition, a foreign firm's entry seems to stimulate the selection process not only within the industry but also through backward linkages in the upstream supplying industries. Regarding the productivity spillover effects from foreign to local firms the results suggest that they mostly operate through vertical linkages rather than within the same industry.
\end{abstract}

JEL classification: F23, L11, L25, C23

Key words: foreign direct investment, firm selection process, crowding out, productivity spillovers, Slovenia

Contact details:

Faculty of Economics

University of Ljubljana

Kardeljeva pl. 17

1000 Ljubljana

Slovenia

Phone: + 38615892400

Fax: + 38615892698

e-mail: katja.zajc@ef.uni-lj.si 


\section{Non-technical summary}

This paper examines the role of inward FDI in firm selection processes in a small transition country of Slovenia. It adopts the firm dynamics framework that allows the testing of these effects directly through the influence on the crowding out of local firms by assessing the impact of the entry and presence of foreign firms on a domestic firm's probability of exiting. By applying heteroscedastic pooled probit model and random effects probit estimator and testing for the robustness of the results by controlling for the possible endogeneity of the foreign ownership variable and endogeneity that is caused by unobserved firm-specific effects to the panel data of Slovenian manufacturing firms in the 1994-2003 period the paper provides evidence that theoretically predicted channels through which inward FDI affects the firm dynamics in a host country (competition effect and productivity spillovers) prove to be in general significant.

First, there is evidence of the direct impact of foreign firms on a change in the population of Slovenian manufacturing firms. Not only do foreign entrants tend to be above-average productive but they also find it easier to exit (particularly those entering in the form of acquisitions), confirming that on average they are more mobile than their domestic counterparts.

Second, the entry of foreign firms stimulates the selection process and reallocation of resources among firms within the same industry based on their productive efficiency. The firm selection process is, namely, characterised by the least efficient firms experiencing a drop in their survival probability upon a foreign firm's entry. On the other hand, more efficient and more skill-intensive firms do not experience any pronounced 'static' crowding out with respect to the increased probability to exit. In addition, a foreign firm's entry seems to stimulate the selection process not only within the industry but also through backward linkages in the upstream supplying industries as indicated by less skillintensive firms' increased probability of exiting when the concentration of foreign firm activity in backwardly-linked industries rises.

Third, regarding the productivity spillover effects from foreign to local firms the results suggest that they mostly operate through vertical linkages rather than within the same industry. The impact of foreign firms' activity on the survival probability through forward linkages with local customers is the most pronounced. In general, it seems that not all firms are equally able to benefit from a foreign firm's presence and that absorptive capacity plays an important role. 


\section{Introduction}

The paper aims to provide a deeper understanding of the role of incoming foreign direct investment (FDI) in the firm selection process within domestic industries in a small transition country of Slovenia. Several recent empirical studies provide evidence that within-industry reallocations from less to more productive firms and the exit/entry process contribute significantly to average productivity growth and constitute an important mode of industrial restructuring (see Olley and Pakes (1996), Roberts and Tybout (1996), Pavcnik (2002), Tybout (2001)). At the same time, it is widely recognised that investment liberalisation is one of the most important triggers of the industrial restructuring process driven by intra- and inter-industry firm selection processes. The paper adopts the firm dynamics framework and assesses the impact of the entry and presence of foreign firms on a domestic firm's probability of exiting based on a panel of Slovenian manufacturing firms in the last decade.

As indicated in the theoretical literature (reviewed in, for example, Caves (1996), Blomström and Kokko (1997, 1998)), there are two main opposing effects through which inward FDI can affect a domestic firm's survival and performance: competition effect and productivity spillover effects. The entry of a foreign firm (either through exports or FDI) namely disturbs the existing equilibrium in the host country and increases the intensity of competition. The competition also intensifies if the foreign firm was exporting prior to establishing local production in the host-country market since, by avoiding export costs, the foreign firm's competitive position is improved. The competition effect of inward FDI (a foreign firm's entry/presence) has clear implications for the exit and growth of domestic firms. By increasing competition in the host country, a foreign firm's entry and presence may lead to the crowding out of local firms. The entry of a foreign firm with lower marginal costs draws demand away from domestic firms as the foreign firm has an incentive to increase production relative to its domestic competitors. Domestic firms are then forced to cut production and the least productive ones even to exit the market. As emphasised by Görg and Strobl (2003), regardless of the cost structure the increased production of foreign rivals will generally lead to a reduction of the output price which will shrink the price-cost margin and increase the probability of the exit of domestic firms and reduce the prospects for their future growth. However, some local rivals might react to this intensified competition by investing in product and/or process upgrading or by merging. The competition effect may also operate in the factor markets, whereby foreign firms may crowd out domestic rivals by increasing factor prices in the economy. Moreover, a selection effect might also operate through vertical linkages when the degree of linkages might be weaker in the case of MNEs compared to domestic firms, leading to a decrease in demand for intermediate products. As pointed out by Smarzynska (2004) and Saggi (2002), MNEs' entry to downstream sectors might lower the demand for domestically produced intermediates, particularly when it forces less productive domestic producers in this industry to exit. The demand for domestically produced intermediates might decrease either because they use inputs more efficiently or they rely more on imported intermediates (see Rivera-Batiz and Rivera-Batiz, 1991). In addition, some local suppliers might not be able to achieve the higher product standards or delivery conditions demanded by foreign firms.

On the other hand, foreign firms' activity in the host country may confer positive productivity spillovers on domestic firms. ${ }^{1}$ Since productivity is one of the key determinants of whether or not a firm exits and of the prospects of its growth, through spillover effects FDI also indirectly positively affects the domestic firm's survival and its growth performance An increase in productivity through technological spillovers will, ceteris paribus, reduce a domestic firm's average production costs which

\footnotetext{
${ }^{1}$ These externalities may appear since 'technology' is to some extent a public good, there is a belief that foreign firms may not be able to fully internalise their technological advantages and therefore their presence would lead to various types of 'productivity spillovers' to domestic firms.
} 
in turn expands its price-cost margin. Thus, in the case of positive technological spillovers we can expect a greater probability of survival. However, several studies assert that local firms must have an ability to learn and take advantage of the technology employed in multinational enterprises (MNEs). This so-called absorptive capacity is often related to the skill intensity and learning experiences of the firm. A domestically-owned firm might benefit from the presence of foreign firms through several potential channels: (i) through the backward and forward linkages (customer-supplier links) between MNEs and domestic firms; (ii) MNEs' training of local employees; (iii) demonstration effects; and (iv) competition from MNEs. Productivity spillovers may thus occur within the same industry (intraindustry spillovers), in vertically - upstream and downstream - related industries (inter-industry spillovers), or as a result of agglomeration (see Blomström and Kokko, $(1997,1998)$ ).

The nature of these effects and the relative importance of the channels depend on a number of FDI characteristics. As pointed out by Kosová (2004) to distinguish and estimate both effects separately two different measures of foreign firm entry and presence should be included in an empirical model's specification. While there is a substantial body of empirical literature on spillover effects, evidence of the importance and mechanisms of competition effects is relatively rare. Moreover, most studies test the presence of productivity spillovers by estimating the production function on the level of firms or plants without controlling for the fact that FDI might have a significant impact on the exit of domestic firms. Several authors argue that FDI's impacts and, in particular, the competition/selection effect are better analysed from the perspectives of industry and firm dynamics. Accordingly, that is the framework I have chosen for the empirical analysis. More specifically, I estimate a firm exit model using firm-level data for the Slovenian manufacturing sector in the 1994-2003 period. The firm dynamics framework allows the assessing of the competition effect and in particular the role of inward FDI in the industry selection process more directly through its impact on the crowding out of local firms (increased probability of exiting). At the same time, this framework also allows me to indirectly test for productivity spillover effects since productivity is one of the main determinants of a firm's survival.

Despite the relatively numerous empirical studies on a firm's survival and growth, empirical evidence of the impacts of inward FDI or even of foreign competition generally on the growth and survival of local firms is very limited. The rare exceptions are studies by Görg and Strobl (2003) for Ireland, De Backer and Sleuwaegen (2003) for Belgium, and Kosová (2004) for the Czech Republic. Using plantlevel data for the Irish manufacturing sector in the 1973-1996 period and employing a Cox proportional hazard model, Görg and Strobl (2003) find that the presence of multinationals has a positive effect on the survival of Irish plants but this effect is only significant for plants that operate in high-tech sectors. Regarding foreign-owned plants, they provide evidence that foreign plants have higher hazards of exiting than indigenous plants and that the presence of multinationals has a negative effect on the survival of other foreign-owned plants in low-tech sectors. On the contrary, De Backer and Sleuwaegen (2003) find evidence that inward FDI increases domestic exits by separately estimating exit and entry functions for Belgian manufacturing data. The crowding-out effect is stronger in the case of FDI than in the case of imports. Moreover, they find that increased foreign competition both through increased imports and inward FDI negatively affects the entry of domestic firms. However, the empirical results suggest that the importance of positive long-term structural effects measured by the relative number of foreign firms in related industries (defined as industries belonging to the same NACE-2 digit level) between foreign and domestic firms can moderate or even reverse crowding-out effects. Distinguishing between static and dynamic crowding-out effects of domestic firms by foreign ones and technological spillover effects in survival and growth models using 1994-2001 firm-level panel data for the Czech Republic, Kosová (2004) provides evidence that foreign expansion, measured by the foreign sales growth rate, has a positive effect on both the growth and survival of domestic firms. These results, together with the significantly higher exit rates of 
domestic firms around the time of a foreign entry, suggest that crowding out, and thus the adjustment of domestic firms to FDI inflows, is merely a one-time static effect realised upon foreign entry. So there is a shakeout of domestic firms when foreign firms enter but, subsequent to this initial entry effect, domestic firms benefit from the expanding foreign industry.

The rest of the paper is organised as follows. Section 2 sets up theoretical framework for the empirical model's specification. In Section 3, the data and main descriptive statistics with respect to domesticand foreign-owned firms are presented. Section 4 specifies an exit model to be applied to panel data for Slovenian manufacturing firms and defines the variables. Section 5 discusses the main econometric problems dealt with in the empirical analysis. Further, Section 6 presents the results and implications of the empirical estimations. Finally, Section 7 concludes with a summary of the main findings of the empirical analysis.

\section{Theoretical framework for the empirical model's specification}

Both the theoretical and empirical literature often studies firm exits and growth together as an outcome of a single economic process of industrial evolution. Most recent studies adopt the framework of socalled firm and industry dynamics models which focus on the selection process among heterogeneous firms within a particular industry that operates through the entry and exit process and emphasise the importance of firms' learning process for the selection and evolution process within the industry. These models are thus also known as 'learning models' as the entrant typically does not know its own cost structure (efficiency), but it is discovered through the processes of passive (Jovanovic, 1982) or active learning (Erikson and Pakes, 1995) from actual market experience subsequent to entry. These theories can explain some of the empirical regularities that appear to be crucial for understanding the process of firm exits and growth (see Sutton, 1997). In particular, the size-age-growth relationship: larger firms tend to have lower growth rates but are more likely to survive. Further, for any given size of firm the proportional growth rate is smaller the older the firm is yet its probability of survival is greater.

Recently, models of industry dynamics with heterogeneous firms have been integrated into general equilibrium trade models by Bernard, Eaton, Jensen, and Kortum (2003) and Melitz (2003). The models focus on the effects of increased foreign competition through the lowering of trade barriers on evolution processes within industries. While they are similar in their main prediction that trade liberalisation forces the least efficient firms to contract or exit while promoting the growth and success of more efficient ones, they differ with respect to channels and motivations. The models of firm and industry dynamics that also account for foreign competition are almost exclusively based on trade and do not consider the FDI entry mode.

I chose a general dynamic model of heterogeneous firm behaviour that mostly follows Olley and Pakes' (1996) model and its empirical application in Bernard and Jensen (2002) as the framework for the empirical model's specification. This framework is general enough to allow the testing of various predictions of FDI's impacts on domestic firms' survival in the Slovenian manufacturing sector in the 1994-2003 period.

The firm is assumed to maximise the expected discounted value of its future net cash flows. A singleperiod net cash flow is equal to the current profit $\pi_{t}$ minus the cost of the current investment $c\left(i_{t}\right)$, where $i_{t}$ is the level of investments. Current profits are assumed to be a function of the set of the firm's own state variables $\lambda_{t}$, factor prices $\tau_{t}$, which are assumed to be common across firms and to evolve 
according to an exogenous first-order Markov process, a vector of state variables $\gamma_{t}$ that summarises the market structure of the domestic industry including the firm's own prior investment history, and the set of a exogenous factors $\theta_{t}$ that reflects conditions outside the domestic industry $\left(\pi_{t}\left(\lambda_{t}, \theta_{t}, \tau_{t}, \gamma_{t}\right)\right)$. According to Olley and Pakes' model, the firm's own state variables $\lambda_{t}$ include the age of the firm $a_{t}$, the firm's capital stock $k_{t}$, and an index of the firm's efficiency $\omega_{t}^{2}\left(\lambda_{t}=\left(a_{t}, k_{t}, \omega_{t}\right)\right)$.

At the beginning of every period, an incumbent firm has the following decisions to make:

- the first is to decide whether to exit or continue to operate. If it exits, it receives a liquidation value of $\varphi$.

- provided a firm decides to continue, it chooses variable factors (labour) and a level of investments $\left(\mathrm{i}_{\mathrm{t}}\right){ }^{3}$

The general Bellman value function for the dynamic programme of the firm that maximises the expected discounted value of its future net cash flows can then be written as:

$$
\mathrm{V}_{\mathrm{t}}\left(\lambda_{\mathrm{t}}, \theta_{\mathrm{t}}, \tau_{\mathrm{t}}, \gamma_{\mathrm{t}}\right)=\max \left\{\varphi, \sup \pi_{\mathrm{t}}\left(\lambda_{\mathrm{t}}, \theta_{\mathrm{t}}, \tau_{\mathrm{t}}, \gamma_{\mathrm{t}}\right)-\mathrm{c}\left(\mathrm{i}_{\mathrm{t}}\right)+\beta \mathrm{E}\left[\mathrm{V}_{\mathrm{t}+1}\left(\lambda_{\mathrm{t}+1}, \theta_{\mathrm{t}+1}, \tau_{\mathrm{t}+1}, \gamma_{\mathrm{t}+1}\right) \mid \mathrm{J}_{\mathrm{t}}\right]\right\}
$$

where $\pi_{t}(\cdot)$ is the restricted current profit function, $\beta$ is the firm's discount factor, and $\mathrm{J}_{\mathrm{t}}$ represents the information available at time $t$.

The solution to this problem gives an exit rule and an investment demand function. Only if the ongoing value of the firm is greater than the liquidation value does the firm choose a non-negative value of investment. If the indicator function $\chi_{t}$ is defined to be 1 if the firm exits, then the exit rule and investment demand equation are specified, respectively, as:

$$
\chi_{t}=\left\{\begin{array}{l}
1 \text { if } d_{t}<\underline{d}_{t}\left(\lambda_{t}, \theta_{t}, \tau_{t}, \gamma_{t}\right), \\
0 \text { otherwise, }
\end{array}\right.
$$

and

$$
i_{t}=i_{t}\left(\lambda_{t}, \theta_{t}, \tau_{t}, \gamma_{t}\right)
$$

The functions $\underline{d}_{t}\left(\lambda_{\mathrm{t}}, \theta_{\mathrm{t}}, \tau_{\mathrm{t}}, \gamma_{\mathrm{t}}\right)$ and $i_{t}\left(\lambda_{t}, \theta_{t}, \tau_{t}, \gamma_{t}\right)$ are determined as part of Markov's perfect Nash equilibrium and will depend on all parameters determining the equilibrium behaviour, including the market structure and the factor prices prevalent when these decisions are made.

In the paper I focus only on the exit decision. I choose a probit model as the parametric specification of exit decision function (2) given by:

$$
\operatorname{Pr}\left(\text { dexit }_{i t}=1 \mid X_{i t}\right)=\Phi\left(X_{i t} \beta\right),
$$

\footnotetext{
${ }^{2}$ The index of productivity, $\omega$, is known to the firm and evolves over time according to an exogenous Markov process. The distribution of $\omega_{\mathrm{t}}$ conditional on all information known at $t$ is determined by the family of distribution functions $\mathrm{F}_{\omega}=\{\mathrm{F}(\cdot \mid \omega), \omega \in \Omega\}$.

${ }^{3}$ The capital stock at the beginning of the next period is thus determined by $\mathrm{k}_{\mathrm{t}+1}=(1-\delta) \mathrm{k}_{\mathrm{t}}+\mathrm{i}_{\mathrm{t}}$.
} 
where dexit ${ }_{\text {it }}$ is the dependent binomial variable, which takes the value of 1 in the year of a firm's exit and 0 for all previous years and $\mathrm{X}_{\mathrm{it}}=\left(\lambda_{\mathrm{t}}, \theta_{\mathrm{t}}, \tau_{\mathrm{t}}, \gamma_{\mathrm{t}}\right)$.

\section{The data}

The firm's exit function is estimated based on annual panel data on firms operating in the Slovenian manufacturing sector (NACE 15-37) in the 1994-2003 period ${ }^{4}$. One of the advantages of this dataset is that, unlike in most studies on FDI that restrict the sample to larger firms, it covers the whole population of manufacturing firms as reporting is mandatory for all firms (business entities) registered in Slovenia. Originally, the dataset contained information on 9,711 firms operating between 1994 and 2003 but firms with a zero number of employees and a negative value of equity were dropped from the sample which gives 7,652 firms in the final sample.

The year of exit is defined according to the effective definition of market operations. The official year of the termination of operations as recorded in the Business Register is thus corrected if the firm stopped being active in the market already before the official year of termination. The bankruptcy process usually lasts for several years, and a firm terminates all of its regular operations a year or even more before the date of termination is officially recorded in the register, therefore in this case I define as the year of exit the last year of a firm's effective operation defined by positive sales and employment according to annual accounting data. The data cover the ten-year period between 1994 and 2003 but, as effective exits in 2003 and effective entries in 1994 cannot be identified, the effective sample on which the empirical estimations are performed is restricted to the 1995-2002 period.

Foreign-owned firms are defined as firms in which foreign owners have at least a $10 \%$ equity share. For the purpose of distinguishing between the different types of FDI, foreign acquisitions are identified as those firms that record a switch from being classified as a domestic firm in the previous year to being classified as a foreign firm in the year of acquisition, while where a firm already has foreign ownership in the first year of its operation the foreign investment is considered a greenfield investment provided that the $10 \%$ foreign ownership threshold is achieved. The main descriptive statistics and indicators of the importance of foreign firms in the Slovenian manufacturing sector are presented in Tables 1 and 2.

There is a notable and persistent difference between domestic and foreign firms with respect to all characteristics seen in the Table 1. As expected, throughout the whole period foreign firms demonstrated a higher average size, higher labour and total factor productivity and higher capital intensity compared to domestic firms with the only exception of capital intensity in 2002. Foreign firms also pay higher average wages and are more export-oriented than their domestic rivals, selling around half of their output abroad. A slight convergence between domestic and foreign firms can be seen in terms of average labour productivity, which for domestic firms increases by approximately $80 \%$ versus the $60 \%$ increase in the average labour productivity of foreign firms within the 1994-2003 period. On the other hand, domestic firms have been unable to decrease the gap in total factor productivity. The average total factor productivity of domestic firms remains practically unchanged throughout the period, while foreign firms face an approximate $30 \%$ increase compared to the initial year 1994. The data suggest that if the constant returns to scale is an acceptable assumption then the value-added increase per employee (labour productivity) of domestic firms can be almost exclusively

\footnotetext{
${ }^{4}$ Financial data were obtained from the database of firms' financial statements collected by the Agency of the Republic of Slovenia for Public Legal Records and Related Services. The data on firms' formation, legal and organisational forms and termination of operation were obtained from the Business Register of Slovenia. Other data were provided from the Statistical office of Republic of Slovenia.
} 
attributed to the improvement in the capital equipment of labour (on the assumption of constant returns to scale), while improvements in total factor productivity play an important role in foreign firms.

Table 1: Average size, labour and total factor productivity, real average annual wage and export propensity of domestic and foreign firms in the Slovenian manufacturing sector, 1994-2003

\begin{tabular}{|c|c|c|c|c|c|c|c|c|c|c|c|c|}
\hline & \multicolumn{2}{|c|}{ Employment } & \multicolumn{2}{|c|}{$\begin{array}{c}\text { Labour } \\
\text { productivity } \\
1000 \text { SIT } \\
\text { (1994 prices) }\end{array}$} & \multicolumn{2}{|c|}{$\begin{array}{c}\text { TFP } \\
\text { dom. firm in } \\
\text { y. 1994=100 }\end{array}$} & \multicolumn{2}{|c|}{$\begin{array}{c}\text { Annual wage } \\
1000 \text { SIT } \\
\text { (1994 prices) }\end{array}$} & \multicolumn{2}{|c|}{$\begin{array}{c}\text { Capital- } \\
\text { intensity } \\
1000 \text { SIT } \\
\text { (1994 prices) }\end{array}$} & \multicolumn{2}{|c|}{$\begin{array}{c}\text { Export } \\
\text { propensity }\end{array}$} \\
\hline & or & For & Dom & For & Dom & For & Dom & & Dom & For & $\bar{n}$ & $\mathbf{F}$ \\
\hline 199 & 62 & & 1963 & 1070 & 11 & 121 & 724 & & 4139 & 6459 & 0.16 & 0.47 \\
\hline 199 & & & 32 & & 0 & & & & 25 & 4170 & 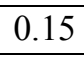 & 45 \\
\hline 1996 & 49 & & 32 & 8 & 103 & 132 & 34 & & 517 & 5792 & 5 & .48 \\
\hline 1997 & 44 & & 417 & 2924 & 0 & 14 & 985 & & 748 & 6133 & 6 & 0.47 \\
\hline 1998 & 41 & & 448 & 52 & 100 & 150 & 045 & & 364 & 7398 & 6 & .50 \\
\hline 1999 & 40 & & 2711 & , & 102 & 163 & 1139 & & 141 & 7745 & .16 & 0.50 \\
\hline 000 & 36 & & 16 & & 01 & 170 & 194 & & 324 & 9330 & 0.16 & 0.54 \\
\hline 2001 & נד & & 3070 & & 102 & 164 & 1281 & & 627 & 8293 & .16 & 0.59 \\
\hline 002 & 38 & & 3406 & 4107 & 102 & 148 & 1377 & & 8214 & 8089 & 0.16 & 0.55 \\
\hline 003 & 37 & & 3542 & 4635 & 102 & 155 & 1477 & 1886 & 8159 & 10940 & 0.16 & 0.58 \\
\hline
\end{tabular}

Note: summary statistics exclude firms with 0 employees and which reported non-positive equity.

Source: own calculations

In Table 2 selected indicators of the importance of foreign firms in the Slovenian manufacturing sector are reported to motivate expectations regarding the impacts of foreign firm entry and their presence on the survival of domestic firms. As can be seen in Table 2, the importance of foreign-owned firms increased during the period considered according to all measures as a share in the number of firms, employment, fixed assets and value added. At the end of our period, foreign firms accounted for approximately $18 \%$ of manufacturing employment and above $20 \%$ of both fixed assets and value added.

Table 2: The relative importance of foreign firms in the Slovenian manufacturing sector according to selected indicators, 1994-2003

\begin{tabular}{|l|c|c|c|c|c|c|}
\hline & \multicolumn{3}{|c|}{ No of firms } & Empl & Fixed assets & value added \\
\hline & Domestic & Foreign & $\begin{array}{c}\text { For. firm } \\
\text { share }\end{array}$ & $\begin{array}{c}\text { For. firm } \\
\text { share }\end{array}$ & $\begin{array}{c}\text { For. firm } \\
\text { share }\end{array}$ & $\begin{array}{c}\text { For. firm } \\
\text { share }\end{array}$ \\
\hline $\mathbf{1 9 9 4}$ & 3304 & 171 & 4.9 & 8.4 & 11.7 & 12.4 \\
\hline $\mathbf{1 9 9 5}$ & 3910 & 186 & 4.5 & 8.6 & 11.3 & 12.3 \\
\hline $\mathbf{1 9 9 6}$ & 4175 & 243 & 5.5 & 10.1 & 14.6 & 13.4 \\
\hline $\mathbf{1 9 9 7}$ & 4377 & 246 & 5.3 & 10.7 & 16.1 & 14.5 \\
\hline $\mathbf{1 9 9 8}$ & 4437 & 256 & 5.5 & 13.1 & 19.8 & 17.7 \\
\hline $\mathbf{1 9 9 9}$ & 4573 & 247 & 5.1 & 13.0 & 19.1 & 18.7 \\
\hline $\mathbf{2 0 0 0}$ & 4607 & 300 & 6.1 & 21.4 & 33.5 & 32.4 \\
\hline $\mathbf{2 0 0 1}$ & 4693 & 284 & 5.7 & 17.6 & 22.1 & 23.2 \\
\hline $\mathbf{2 0 0 2}$ & 4782 & 347 & 6.8 & 20.5 & 26.0 & 27.8 \\
\hline $\mathbf{2 0 0 3}$ & 4912 & 297 & 5.7 & 18.2 & 22.5 & 21.5 \\
\hline
\end{tabular}

Note: summary statistics exclude firms with 0 employees. Source: own calculations 
Since the main concern is the impact of the entry of foreign firms on the exit of local firms, I report in Table 3 the entry and exit rates in our sample of firms in the manufacturing sector. According to the effective definition, entry rates were highest (well above 10\%) at the beginning of the period and then calmed down to around $6-8 \%$, while exits (exit rates) reached their peak at $6 \%$ in the middle of the period considered.

Although the share of foreign greenfield entrants in the total number of entrants never exceeds $5 \%$ in the 1995-2003 period (see Table 4), it is far from negligible when the fact is considered that foreign entrants are on average significantly larger than domestic entrants (an average of 36 employees in greenfield entrants versus an average of 19 employees in domestic entrants). In 1996, greenfield entrants accounted for almost $17 \%$ of total employment created by firms that entered the market in 1996. This is not surprising as, due to the larger size of their parent companies, foreign entrants are in a better position to raise funds to finance their entry on a larger scale. When judging the importance of a foreign entry we also have to consider an entry through a foreign acquisition ${ }^{5}$ which accounts for almost $70 \%$ of foreign firm 'entries' in terms of the number of firms and much more in terms of employment as the average size of a foreign acquisition is 3.5 times larger than that of a greenfield entrant and almost 7 times larger than the size of domestic entrants. It is interesting that the average size of firms in the year of their foreign acquisition is larger than the average size of foreign acquisition firms in the years after the foreign acquisition happened, which suggests that foreign investors carry out certain rationalisations in terms of reducing employee numbers.

Table 3: Firm entry and exit patterns in the Slovenian manufacturing sector, 1994-2003

\begin{tabular}{|l|c|c|c|c|c|}
\hline & $\begin{array}{c}\text { No. of } \\
\text { entrants }\end{array}$ & $\begin{array}{c}\text { No. of } \\
\text { exits }\end{array}$ & $\begin{array}{c}\text { No. of active } \\
\text { firms }\end{array}$ & Entry rate & Exit rate \\
\hline $\mathbf{1 9 9 4}$ & & 83 & 3459 & & 0.024 \\
\hline $\mathbf{1 9 9 5}$ & 797 & 217 & 4173 & 0.191 & 0.052 \\
\hline $\mathbf{1 9 9 6}$ & 573 & 269 & 4529 & 0.127 & 0.059 \\
\hline $\mathbf{1 9 9 7}$ & 576 & 244 & 4836 & 0.119 & 0.050 \\
\hline $\mathbf{1 9 9 8}$ & 351 & 268 & 4943 & 0.071 & 0.054 \\
\hline $\mathbf{1 9 9 9}$ & 511 & 226 & 5186 & 0.099 & 0.044 \\
\hline $\mathbf{2 0 0 0}$ & 361 & 201 & 5321 & 0.068 & 0.038 \\
\hline $\mathbf{2 0 0 1}$ & 343 & 249 & 5463 & 0.063 & 0.046 \\
\hline $\mathbf{2 0 0 2}$ & 496 & 220 & 5710 & 0.087 & 0.039 \\
\hline $\mathbf{2 0 0 3}$ & 389 & 68 & 5879 & 0.066 & \\
\hline
\end{tabular}

Note: summary statistics exclude firms with 0 employees.

The number of active firms throughout the period is greater than the number reported in Table 2 since for some firms data were not reported for the whole period of their operation. In Table 2 I only consider firms that are in the database in a particular year (data were reported), while in Table 3 firms that are not in the database in a particular year but were active before and after the year of missing data are also counted.

Source: own calculations

Table 4 shows that the three types of entrants differ widely with respect to a number of characteristics. Besides the fact that foreign entrants are larger, they also pay higher wages and are more capital-

\footnotetext{
${ }^{5}$ However, foreign acquisitions are not considered in the group of entrant firms, as they were already operating before foreign owners acquire their share (above 10\%) in these firms.
} 
intensive than domestic firms. While the average labour productivity of acquired foreign firms in the year of acquisition is higher than the labour productivity of 'true entrants', there is practically no difference between the average productivity of domestic and greenfield entrants (although there is significant variability across different years).

Table 4: Number of entrants and their average size, labour productivity, capital-intensity and real average annual wage according to the entrants' ownership type in the Slovenian manufacturing sector, 1994-2003

\begin{tabular}{|c|c|c|c|c|c|c|c|c|c|c|c|c|c|c|c|}
\hline & \multicolumn{3}{|c|}{ No of entrants } & \multicolumn{3}{|c|}{ Empl } & \multicolumn{3}{|c|}{ Labour prod. } & \multicolumn{3}{|c|}{ Capital-intensity } & \multicolumn{3}{|c|}{ Wage } \\
\hline & & & & & & & 1000 & T (1994 & prices) & 1000 & T (1994 & prices) & 100 & 0 SIT (1 & 994 p.) \\
\hline & Dom & Green & Acquis & Dom & Green & Acquis & Dom & Green & Acquis & Dom & Green & Acquis & Dom & Green & Acquis \\
\hline 1995 & 784 & 13 & 7 & 21 & 40 & 12 & 1659 & 2160 & 1585 & 4310 & 4518 & 1085 & 586 & 845 & 615 \\
\hline 1996 & 548 & 25 & 53 & 17 & 75 & 42 & 1779 & 3678 & 2294 & 3849 & 14560 & 4813 & 617 & 791 & 1315 \\
\hline 1997 & 553 & 23 & 19 & 24 & 22 & 125 & 2497 & 774 & 3034 & 5202 & 13360 & 5910 & 797 & 912 & 1310 \\
\hline 1998 & 341 & 10 & 14 & 19 & 54 & 173 & 1057 & 1354 & 3593 & 4544 & 24789 & 8502 & 712 & 1560 & 1498 \\
\hline 1999 & 509 & 2 & 0 & 18 & 1 & & 2455 & 2775 & & 3810 & 7129 & & 931 & 213 & \\
\hline 2000 & 348 & 13 & 96 & 20 & 44 & 198 & 2125 & 5152 & 3825 & 7862 & 10894 & 10206 & 899 & 1850 & 1615 \\
\hline 2001 & 333 & 10 & 31 & 14 & 16 & 123 & 2676 & 1512 & 2983 & 4998 & 7094 & 3619 & 852 & 912 & 1547 \\
\hline 2002 & 476 & 20 & 59 & 25 & 8 & 105 & 3288 & 2056 & 3074 & 12696 & 8976 & 5668 & 1101 & 1209 & 1607 \\
\hline 2003 & 372 & 17 & 4 & 10 & 26 & 24 & 3569 & 1064 & 2135 & 12686 & 28297 & 3161 & 1163 & 1676 & 2384 \\
\hline \multicolumn{16}{|c|}{ 1995-2003 } \\
\hline entrants & & & & 19 & 36 & 128 & 2296 & 2242 & 3146 & 6336 & 14025 & 6830 & 823 & 1155 & 1509 \\
\hline \begin{tabular}{|l|}
$\begin{array}{l}\text { Non } \\
\text { entrants }\end{array}$ \\
\end{tabular} & & & & 45 & 123 & 97 & 2656 & 3596 & 3548 & 5170 & 7283 & 6708 & 1135 & 1544 & 1538 \\
\hline
\end{tabular}

Note: summary statistics exclude firms with 0 employees.

Source: own calculations

The above-average performance of foreign firms and their larger size upon entry satisfy the principal starting point of theories on MNEs, postulating that to be able to compensate for the inherent disadvantages of operating in foreign markets MNEs must possess certain capabilities which give them some sort of competitive advantage over their domestic rivals. The question open to empirical testing is then whether foreign firms with their superior performance have a significant impact on the survival of local firms and thus firm selection processes in the way the theory suggests.

\section{Empirical model specification and a description of the variables}

According to the exit model specification (4) the factors that affect a firm's exit decision are classified in four groups: (i) firm characteristics $\left(\lambda_{\mathrm{t}}\right)$; (ii) industry or product market characteristics $\left(\gamma_{\mathrm{t}}\right)$, (iii) factor prices $\left(\tau_{t}\right)$; and (iv) other exogenous factors $\left(\theta_{t}\right)$ that reflect conditions outside the domestic industry $\left(\tau_{\mathrm{t}}\right.$ and $\theta_{\mathrm{t}}$ factors are both captured by the inclusion of annual dummies). Various factors proposed by different theoretical models and empirical studies are included in empirical specifications. A higher-order logarithmic expansion in two principal firm-specific variables (firm's size and age) was tested until there is no evidence of further nonlinearity. Similarly as in several other studies, a second-order logarithmic expansion in a firm's size and age and a first-order logarithmic expansion in other variables was confirmed which yields the following regression equation of the firm exit model (4):

$\operatorname{Pr}\left(\right.$ dexit $\left._{i t}=1\right)=\beta_{0}+\beta_{1}$ MNEentry $y_{j t}+\beta_{2}$ MNEentry $\cdot$ dTFPlow $_{j t}+\beta_{3}$ dTFPlow $_{i j t}+\beta_{4}$ entry $y_{j t}+$ 


$$
\begin{aligned}
& \beta_{5} h F D I_{j t}+\beta_{6} h F D I \cdot \ln W_{a g e} e_{i j t}+\beta_{7} \operatorname{ReghFDI}_{j r t}+\beta_{8} \text { BackFDI }_{j t}+\beta_{9} \text { BackConc }_{j t}+\beta_{10} \text { ForFDI }_{j t}+ \\
& \beta_{11} \text { ForConc }_{j t}+\beta_{12} \text { IMint }_{j t}+\beta_{13} \text { IMint }_{j t} \text { COMPL }_{j t}+\beta_{14} \text { COMPL }_{j t}+\beta_{15} \text { fdi }_{i j t}+\beta_{16} H H I_{j t}+\beta_{17} \text { plants }_{i j}+ \\
& \beta_{18} \text { dexport }_{i t}+\beta_{19} \text { dexmajor }_{i t}+\beta_{20} \text { dprofit }_{i j t}+\beta_{21} \operatorname{lnEmpl} \text { ijt }_{1}+\beta_{22} \operatorname{lnEmpl}_{i j t}+\beta_{23} \ln \operatorname{lint}_{i j t}+\beta_{24} \operatorname{lnTFP}_{i j t}+
\end{aligned}
$$

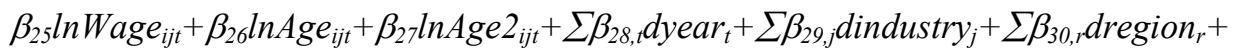

$$
\begin{aligned}
& \sum \beta_{31, o} \text { downertype }{ }_{l}+\eta_{i}+\varepsilon_{i j t}
\end{aligned}
$$

where subscripts $i, j$ and $t$ refer to firms, industries and years, respectively. Ln in variable names denotes the natural logarithm of a particular variable, while 2 (sq) denotes that the variable enters the estimation in a squared form. All values of the financial variables are deflated using producer prices indices at the 2-digit NACE classification.

\section{Firm characteristics}

Among the principal firm characteristics that affect a firm's exit decision the theories postulate a firm's size, age and productivity. The size of a firm ( $\left(\mathrm{empl} l_{i j t}\right)$ is measured by the number of employees. $A g e_{i j t}$ denotes a firm's age counting from its formation year according to the Business Register. As age enters our empirical models in a logarithmic form I start to count age with a value of 1 in order to prevent the dropping of observations in the first year of a firm's operation, which would generate sample selection bias due to the relatively high infant mortality rates. I also test the robustness of the results by including an age variable in a non-logarithmic form and the results are robust. Productivity is measured as total factor productivity $\left(T F P_{i j t}\right)$ based on production function estimates (see the next section). Firm dynamics models predict that smaller and younger firms are less likely to survive but they grow faster than old and large firms. This predicted size-growth relationship sharply contradicts Gibrat's traditional law of independence between the growth of a firm and its size. The productivity of the firm is expected to negatively affect the likelihood of an exit.

Further, I include capital-intensity Kint intensity of a firm is expected to positively affect its ability to survive and grow. According to the Olley and Pakes (1996) model, the stock of physical capital affects the distribution of future plant productivity $^{6}$. In this case, capital intensity may act as a proxy for other unobserved sources of efficiency leading to the higher likelihood of an exit and lower growth for low-capital-intensity plants.

Wage $_{i j t}$ is defined as the average yearly real wage per employee. Unfortunately, data on the skill structure of employees is not available; therefore I also use the wage variable as a proxy for the skill intensity of a firm. This implies I am assuming that wages for similar education level/qualification categories of workers are similar across firms and industries. The real wage is also used as a proxy for human capital in Mata and Portugal (2004). Skill intensity is expected to positively affect a firm's survival ability and its growth potential as it can serve as a proxy for its absorptive and learning capacity, which is a key determinant of the course of a firm's life.

As I use a firm as a unit of observation I must control for the number of firm i's subsidiaries (plants $i j$ ) as the theory and empirical evidence suggests that hazard and growth rates differ between a singleand multi-plant firm. Among the firms' characteristics I additionally control for a firm's profitability by including the dummy variable dprofit $_{i j t}$ which equals 1 for firms with a positive net profit in year $t$. For testing the impact of the exporting two additional dummy variables are included: dexport ${ }_{i t}$ and dexmajor $_{i t}$. dexport ${ }_{i t}$ equals 1 for all exporters (positive sales in foreign markets), while dexmajor ${ }_{i t}$ takes the value of 1 in the case that export propensity - the share of a firm's output supplied to foreign markets in the firm's total sales - is greater than $70 \%$.

\footnotetext{
${ }^{6}$ There is a relationship between a producer's underlying efficiency and the incentive to invest in capital. Essentially, efficient firms generate higher levels of investment and larger capital stocks.
} 


\section{Industry characteristics}

Besides the time-invariant market characteristics that are captured in the set of industry dummies, I include the Herfindahl-Hirschman index $H H I_{j t}$ to measure market concentration. $H H I_{j t}$ is defined as the sum of the squares of the market shares of all firms within a particular industry at the 5-digit NACE level. The market share of firm $i$ is defined as the share of its domestic market sales in total industry sales in the domestic market (all firms' local sales + imports in industry $j$ ). The expected effect of market concentration it is not so clear-cut. On one hand, the concentration ratio is expected to have a positive impact on the survival and growth of firms. The argument is that the price level is more likely to be elevated above the long-run average cost at the minimum efficient scale (MES) level of output in concentrated industries which may facilitate the survival of suboptimal scale firms which is what typical entrant firms are. On the other hand, firms in highly concentrated markets may be subjected to fierce aggressive behaviour by rivals which may reduce their chances of survival.

The principal explanatory variables in the paper refer to the entry and presence of foreign-owned firms to test for both direct and indirect effects of inward FDI measured by the extent of foreign affiliates' operations in the host country. Concerning the indirect impacts of inward FDI on domestic firm dynamics, I test for the presence and relative strength of two opposing effects as predicted by theory: the competition effect and productivity spillovers.

The competition effect is tested with the entry rate variables MNEentry $y_{j t}$, GREENentry $y_{j t}$, $A C Q U I S e n t r y_{j t}$, and entry $y_{j t}$ at the 3-digit level of the NACE classification. MNEentry $y_{j t}$ denotes the foreign firm entry rate defined as the number of foreign entrants (greenfield and acquisitions) divided by the total number of firms operating in the industry $j$, GREENentry $_{j t}$ and ACQUISentry ${ }_{j t}$ define entry rates considering only greenfield or acquisition entrants, respectively, and entry $y_{j t}$ as an entry rate considering all entrants including domestic and foreign ones. All three measures exclude the firm for which the observation is taken. MNEentry ${ }_{j t}$, GREENentry $y_{j t}$ and ACQUISentry ${ }_{j t}$ test the crowding-out effect which takes place upon foreign firms' entry, while entry $y_{j t}$ serves as a controlling variable to control for the impact of a new firm entry in general. It is possible that all firm entries in a particular industry rather than foreign firm entries alone affect the exit decision and growth of incumbent firms so I therefore want to control for this possibility. As it is quite likely that MNEs are attracted to industries that offer favourable conditions which also stimulates domestic firm entry levels, estimates that do not control for this possibility may lead to an overestimation of the crowding-out effect of foreign firms' entry.

MNEentry.dTFPlow $w_{j t}$ is the interaction term between MNEentry ${ }_{j t}$ and $d T F P l o w_{i j t}$, where dTFPlow ${ }_{\mathrm{ijt}}$ is a dummy variable equal to 1 for firms in the lowest quintile in terms of total factor productivity at the 3digit level of NACE and 0 for other more efficient ones. If the least efficient firms are more likely to be crowded out by the entry of a foreign firm this interaction term should have a negative effect on firm growth and survival (a positive sign in the exit equation).

The presence of horizontal (intra-industry) spillover effects is tested by the variable $h F D I_{j t}$ that measures the concentration of foreign firms in industry $j$ as the foreign firms' share in total industry employment:

$$
h F D I_{j t}=\frac{\sum_{i=1}^{n} e m p l_{i j t} \cdot f d i_{i j t}}{\sum_{i=1}^{n} e m p l_{i j t}}
$$


where $n$ denotes the number of all firms in industry $j$ and empl $l_{i j t}$ denotes the number of employees in firm $i$. $f d i_{i j t}$ is a dummy variable for foreign ownership. It takes a value of 1 for 'foreign firms' considering a 10\% ownership share threshold. The measure excludes the firm for which the observation is taken. The employment share of foreign firms is used in many studies testing the presence of horizontal spillover effects, among others (Barrios et al., 2005), (Keller and Yeaple, 2003), (Görg and Strobl, 2003). Instead of the employment share, other studies also consider foreign firms' share in the industry's output (Smarzynska, 2004), and the relative number of foreign firms (De Backer and Sleuwaegen, 2003). Some studies also take into account the share of foreign equity participation in foreign firms, including (Aitken et al., 1999) and (Smarzynska, 2004).

$h F D I \cdot \ln W^{2} e_{i j t}$ is the interaction term between $h F D I_{j t}$ and $\ln \left(\right.$ Wage $\left._{i j t}\right)$. As described above, I use $\ln \left(\right.$ Wage $\left._{i j t}\right)$ as a proxy for a firm's absorptive capacity. If firms with a higher absorptive capacity are more able to take advantage of a foreign firm's presence in the industry, this term should have a negative sign in the exit equation and thus provide some support for the validity of the theoretical prediction that intra-industry spillover effects are stronger for local firms with a higher absorptive capacity (skill intensity).

$R_{e g h F D I}$ measures regional intra-industry foreign firm concentration in terms of employment share and tests whether any intra-industry spillovers are reinforced when domestically-owned firms are located close to foreign firms. More specifically, it is defined as:

$$
\operatorname{Re} g h F D I_{j r t}=\frac{\sum_{i=1}^{m} e m p l_{i j r t} \cdot f d i_{i j t}}{\sum_{i=1}^{m} e m p l_{i j r t}},
$$

where $m$ denotes the number of firms within industry $i$ and region $r$ (at the NUTS 3 level).

The inter-industry spillover effects are tested through two additional explanatory variables $B a c k F D I_{j t}$ and $F o r F D I_{j t}$ measuring the concentration of FDI in backwardly- and forwardly-linked industries with industry $j$. BackFDI $I_{j t}$ measures the extent of potential contacts between local suppliers and foreign firms (vertical connections between local suppliers and foreign affiliates - customers) and thus tests the presence of 'backward' inter-industry spillovers:

$$
\operatorname{BackFDI}_{j t}=\sum_{k ; k \neq j} \alpha_{j k} \cdot h F D I_{k t}
$$

where technical coefficient $\alpha_{j k}$ denotes the share of product $j$ originating from domestic production that is used by industry $k$ in its intermediate consumption (excluding final use and imports of intermediate products). This variable accounts for the impact of foreign affiliates on their upstream local suppliers, that is for the impact of the concentration of foreign firms in industries to which industry $j$ supplies its output. Following Smarzynska (2004), inputs supplied within an industry are not included since this effect is accounted for by the variable measuring the horizontal spillovers - $h F D I_{j t}$.

The extent of potential contacts between local customers and foreign firms-suppliers (through forward linkages) is measured by ForFDI $_{j t}$ :

$$
\operatorname{ForFDI}_{j t}=\sum_{k ; k \neq j} \delta_{j k} \cdot h F D I_{k t},
$$


where the technical coefficient $\delta_{j k}$ denotes the share of input $k$ in the total intermediate consumption of industry $j .^{7}$ This variable accounts for the impact of foreign affiliates on their downstream local customers (the impact of the concentration of foreign firms in industries that provide inputs for industry $j$ ). A negative and statistically significant coefficient in the exit model would suggest there are indeed positive inter-industry externalities connected to the concentration of foreign-owned firms in vertically-linked industries.

To control for the possibility that the general concentration of economic activity in interrelated industries rather than the concentration of foreign firm activity alone positively affects the survival of local firms and that at the same time FDI is attracted to the prosperous industries, I include BackConc $c_{j t}$ and ForConc F $_{j t}$ as controlling variables and thus avoid any potential overestimation of vertical spillover effects. BackConc B $_{j t}$ and ForConc j $_{t t}$ are defined as backwardly- and forwardly-linked industries' share of total manufacturing employment weighted by technical coefficients $\alpha$ and $\delta$.

IMint $_{\mathbf{j t}}$ measures import intensity as a share of imports in total industry sales in the domestic market (all firms' local sales + imports in industry $j$ ). The degree of complementarity between foreign affiliates' local sales and imports is measured by the degree of their overlapping COMPL $\mathrm{L}_{\mathbf{j} \mathbf{t}}$ :

$$
\mathrm{COMPL}_{\mathrm{jt}}=1-\left|\frac{\operatorname{im}_{j t}-\sum_{n, n \in j} \text { localSales }_{i j t} \cdot f d i_{i j t}}{i m+\sum_{n, n \in j} \text { localSales }_{i j t} \cdot f d i_{i j t}}\right|,
$$

where COMPL $\mathbf{j u}_{\mathbf{j t}}$ ranges between 0 and 1 . It is equal to 0 for industries without overlapping (only imports or only foreign firms' local sales within the industry $j$ ) and approaches 1 for industries with high overlapping. The interaction term between $\mathrm{IMint}_{\mathbf{j t}} \cdot \mathrm{COMPL}_{\mathbf{j t}}$ tests if the impact of imports differs among industries with different levels of complementarity between local sales of foreign affiliates and imports.

To control for the industry-, time- and region-specific effects throughout our 1994-2003 sample period I include annual dummies dyear ${ }_{t}$, industry dummies at the 3-digit level of NACE dindustry ${ }_{j}$, region dummies at the NUTS level dregion $_{r}$, and dummies for ownership type downertype discriminating among different types of ownership.

Several other variables were also tested but, due to insignificant coefficients in all empirical specifications, were not included in final empirical models. Among others, I test for the effect of the ratio of long-term debt to total assets, for the minimum efficient scale defined as the log of median employment size in industry $j$ and industry growth with respect to the previous year defined as the growth of total employment within particular industry $j$.

\footnotetext{
${ }^{7}$ Technical coefficients $\alpha_{\mathrm{jk}}$ and $\delta_{\mathrm{jk}}$ are obtained from the input-output table, more specifically from 'Use table for the domestic output at basic prices'. As the input-output table for the Slovenian economy is not available for all years in our 1994-2003 sample, the year 2000's I-O table was chosen as a base for the technical (input) coefficient calculation. BackFDI $I_{j t}$ and ForFDI ${ }_{j t}$ are constructed at the two-digit level of NACE which is the most detailed level of the I-O table available.
} 


\section{Econometric issues}

\section{Heteroscedasticity}

There are several potential econometric problems of estimating probit exit models with heteroscedasticity being one of the earliest to be identified (e.g. Hall (1987), Evans (1987)). Most models of heterogeneous firm dynamics namely predict that firm size and age affect the conditional variance of the firm's growth and exit decision. Indeed, most studies actually confirmed that the variability of firm growth decreases with firm size suggesting that variance is not constant across firms. To deal with potential heteroscedasticity in exit models I apply a heteroscedastic probit model that generalises the probit model by generalising the cumulative distribution function (CDF) of a standard normal random variable $\Phi()$ with a mean of 0 and variance of 1 to a normal CDF with a variance no longer fixed at 1 but allowed to vary as a function of the independent variables. Following Harvey (1976), the general formulation of the heteroscedastic model is:

$$
\operatorname{Pr}\left(\mathrm{y}_{\mathrm{i}}=1\right)=\Phi\left(\mathbf{x}_{\mathrm{i}} \mathrm{b} / \exp \left(\mathbf{z}_{\mathrm{i}} \gamma\right)\right)
$$

where $\operatorname{Var}\left[\varepsilon_{\mathrm{i}}\right]=\sigma_{i}^{2}=\left[\exp \left(\mathbf{z}_{\mathrm{i} \gamma} \gamma\right]^{2}\right.$.

\section{Unobserved heterogeneity-endogeneity problem}

To control for the possibility that unobserved firm-specific effects are correlated with regressors and thus to obtain consistent maximum likelihood estimates in probit models, I parameterise unobserved heterogeneity (unobserved firm-specific effects $-\eta_{i}$ ) in the manner suggested by Mundlak (1978), Chamberlain (1984), Wooldridge (2002):

$$
\eta_{i}=\alpha_{0}+\alpha_{1} \bar{X}_{i}+u_{i}
$$

where unobserved heterogeneity $\eta_{i}$ is a linear function of a vector of the firm-level means of all timevarying independent variables over the sample period $\left(\bar{X}_{i}\right)$ and $u_{i}$ is assumed to be distributed $\mathrm{N}(0$, $\sigma_{\mathrm{u}}^{2}$ ) and independent of $\boldsymbol{X}$ variables and the idiosyncratic error term $\varepsilon_{\mathrm{it}}$ (Kosová (2004) uses the same approach). In addition, annual industry-level means of all firm-time-varying independent variables $\boldsymbol{X}$ are included to account for the industry-specific shocks that are not captured by the industry characteristics explicitly included in the empirical model specifications.

\section{Endogeneity}

Another potential econometric concern which may cause biased estimates when testing for the direct impact of foreign ownership on a firm's exit decision is the possibility that the foreign ownership dummy variable $\left(f d i_{i j t}\right)$ might not be entirely exogenous. It is usually argued that foreign investors tend to acquire shares in the most successful and larger firms and that foreign ownership is thus not randomly distributed (see Djankov and Hoekman (2000), Evenett and Voicu (2001), Damijan et al. (2003)). In this case, $f d i_{i j t}$ is potentially a choice variable that might be correlated with unobservables relegated to the error term. More specifically, $f d i_{i j t}$ may be endogenous if the decision for FDI (in the form of foreign acquisitions) is correlated with unobservables that affect a firm's exit decision/growth. For instance, if foreign investors are more likely to acquire shares in more successful firms and therefore experience a lower probability of exiting or higher growth ceteris paribus, then if I fail to control for this correlation results will underestimate (overestimate) the effect of foreign ownership on the probability of exiting (growth). 
To deal with this problem I instrument for $f d i_{i j t}$ and employ instrumental variables models. I use the two-stage method proposed by Newey $(1987)^{8}$ for limited dependent variable models with endogenous explanatory variables to estimate the exit model. The instruments employed are size, size squared, age, age squared, the ratio of net profits to sales, export propensity, total factor productivity and average wage. I use lagged values of these instruments for domestic firms, values of the instruments in the year before an acquisition takes place for firms that have been acquired by foreign investors and the firstyear values for greenfield FDI. To avoid autocorrelation the first-year observations for greenfield investments are dropped.

\section{Total factor productivity estimates}

There are additional potential econometric concerns related to the estimation of a firm's total factor productivity. Typically, total factor productivity is estimated as the residual in the production function estimates based on firm-level panel data. ${ }^{9}$ Simultaneity bias is usually referred to as the endogeneity of production inputs, caused by a correlation between unobservable productivity shocks and input levels causing the regressors and the error term to be correlated which makes OLS estimates inconsistent. Bias thus occurs when at least part of the TFP is observed by the firm early enough to allow the firm to change its factor input decision.

Several methods of controlling for simultaneity bias are proposed in the literature. Olley and Pakes (1996) developed an estimator that uses investment as a proxy for these unobservable productivity shocks. One of the drawbacks of Olley and Pakes' (1996) approach is that there must be a strictly monotonous relationship between the proxy (investment) and output for obtaining consistent estimates. This means that observations with a zero investment have to be dropped from the sample. Therefore, to avoid truncating observations with a zero investment I follow Levinsohn and Petrin's (2003) approach and employ their two-step estimator which uses intermediate inputs as proxies. Another of the advantages of this estimator is that intermediates may respond more smoothly to productivity shocks and may respond more fully to the entire productivity term than investment (investment is, namely, associated with substantial adjustment costs).

\section{Results}

The results of the heteroscedastic pooled probit model of a firm's exit (5) with standard error adjusted for firm clusters which specifies that observations are independent only across clusters (firms) but not necessarily within clusters (firms) are reported in Table 5 for the sample of all firms, and in Appendix 1 for the sub-sample of domestically-owned firms. All estimates include means of independent variables to control for unobserved 'correlated' heterogeneity according to (12). For all estimated specifications of the exit model Wald's test of a full versus a constant only model indicates that the full model is significant at negligible risk. While based on Wald's test for heteroscedasticity in the form of $\sigma_{\mathrm{i}}^{2}=\left[\exp \left(\gamma \cdot \operatorname{lnEmpl} \mathrm{l}_{\mathrm{i}}\right)\right]^{2} \mathrm{I}$ reject the null hypothesis of homoscedastic variance (i.e. $\mathrm{H}_{0}: \ln \left(\sigma_{\mathrm{i}}^{2}\right)=0$ ) at negligible risk. The estimated $\gamma$ is negative and ranges between -0.12 and -0.14 which confirms the

\footnotetext{
${ }^{8}$ I perform instrumental variable probit estimates using the STATA module developed by Gelbach (1999, [http://fmwww.bc.edu/repec/bocode/p/probitiv.ado], 5.10.2005)

${ }^{9}$ Assuming a standard Cobb-Douglas production function the following form is obtained:$$
Y_{i t}=A_{i t} \cdot L_{i t}^{\alpha} \cdot K_{i t}^{\beta} \cdot M_{i t}^{\gamma} \text {, }
$$

where $\alpha+\beta+\gamma=1$ would imply constant returns to scale. $Y_{\text {it }}$ denotes the output (gross revenue), $A_{i t}$ is called total factor productivity, $\mathrm{L}_{\mathrm{it}}$ and $\mathrm{M}_{\mathrm{it}}$ are freely variable inputs labour and intermediate inputs (material costs) and $\mathrm{K}_{\mathrm{it}}$ is a measure of the state variable capital.
} 
expected negative relation between variance and a firm's size. For this reason, only probit estimation results corrected for heteroscedasticity are reported.

Besides, I use a random-effects probit estimator to also explicitly account for that part of heterogeneity that is uncorrelated with firm-level means $\left(u_{i}\right)$. The likelihood ratio test which compares the pooled (probit) estimator with the panel estimator with an asymptotic distribution of a 50:50 mixture of chisquare with no degrees of freedom (i.e. the point mass at zero) and a chi-square with 1 degree of freedom fails to reject the homogeneity (the null of no heterogeneity) (Appendix 2). This suggests that the proportion of the total variance contributed by the panel-level variance component $(\rho)$ (after controlling for firm-level means) is unimportant and the panel estimator is not different from the pooled estimator. Therefore, I report and comment on the results based on a pooled probit estimator only, and present random-effects probit estimates in Appendix 2. The results also remain unchanged when corrected for the effects of outliers.

Regarding the key variables, the results of the aggregate sample (Table 5) confirm the expected positive impact of a foreign firm's entry via FDI on the probability of incumbent firms exiting as the estimated coefficient on the variable MNEentry $j_{j t}$ is positive and significant. The evidence of the crowding-out effect upon foreign firms' entry is robust to the inclusion of the controlling variable for the general entry rate. The expectation that a foreign firm's entry does not affect the probability of exiting equally for all operating firms is tested by the inclusion of the interaction term

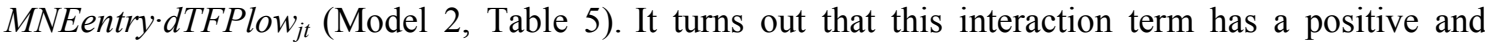
highly significant impact, while $M N E e n t r y j t$ becomes insignificant which indicates that the crowdingout effect is only significant for the least efficient firms from the lowest quintile in terms of total factor productivity, while there is no significant evidence that more efficient firms would suffer a negative impact on their survival probabilities. This result lends support to the prediction that the probability of exiting after a foreign firm entry increases the most among the least efficient firms in the host economy. Expressing the marginal effects at sample mean ${ }^{10} \mathrm{I}$ find that if the foreign firm entry rate increases by one structural point the exit probability increases on average by $8.7 \%$ (Model 1, Table 5), while for the least efficient firms the exit probability increases by almost 24\% (Model 2, Table 5).

While the evidence on the crowding out of local firms upon foreign firm entry is clear, the results are less conclusive regarding the influence of foreign firm concentration within the industry tested with the $h F D I_{j t}$ variable. However, an insignificant coefficient, as also found in a previous study on the Slovenian manufacturing sector by Damijan, Knell, Majcen, and Rojec (2003), cannot be interpreted as an indication of the absence of horizontal spillover effects as it measures the net effect of any positive productivity spillovers and the continuous crowding-out effect. To further explore this effect, I include an additional interaction term between $h F D I_{j t}$ and absorptive capacity measured by the real average wage. It turns out that the expectations are grounded; both coefficients for $h F D I_{j t}$ and $h F D I l n w a g e_{j t}$ become significant at $10 \%$ (Model 2, Table 5). The negative sign of the interaction term suggests that the ability to benefit from MNEs' presence increases with the skill-intensity of a firm and therefore it can be expected that the probability of net positive spillover effects is higher for skillintensive firms identified as those that pay higher average real wages, which points to the importance of the absorptive capacity of firms. The results thus suggest that within those industries facing a significant foreign firm presence a firm's skill-intensity offsets some of the increased probability of exiting and that the probability of survival increases with skill-intensity more rapidly in those industries with a higher concentration of foreign firm activity (in terms of employment share).

\footnotetext{
${ }^{10}$ Marginal effects refer to the marginal probability change at the mean of independent variables or the change in probability for a discrete change in a dummy variable from 0 to 1 .
} 
However, there is no evidence that intra-industry effects would be intensified in the case of the local concentration of foreign firm activity (where local is defined as being located in the same region).

Table 5: Heteroscedastic probit exit model estimates for the aggregate sample of foreign and domestic firms

\begin{tabular}{|c|c|c|c|c|c|c|c|c|}
\hline & Coef. & $\begin{array}{c}\text { Margina } \\
\text { l effects } \\
\text { dP/dX }\end{array}$ & Coef. & $\begin{array}{c}\text { Marginal } \\
\text { effects } \\
\text { dP/dX }\end{array}$ & Coef. & $\begin{array}{c}\text { Margina } \\
\text { l effects } \\
\text { dP/dX }\end{array}$ & Coef. & $\begin{array}{l}\text { Margina } \\
\text { l effects } \\
\text { dP/ dX }\end{array}$ \\
\hline Model & 1 & 1 & 2 & 2 & 3 & 3 & 4 & 4 \\
\hline MNEentry & $\begin{array}{c}2.026^{* *} \\
(2.22)\end{array}$ & 0.0092 & $\begin{array}{l}0.937 \\
(0.87)\end{array}$ & 0.0041 & & & $\begin{array}{c}1.932^{* *} \\
(2.10)\end{array}$ & 0.0086 \\
\hline GREENentry & & & & & $\begin{array}{l}1.814 \\
(1.10)\end{array}$ & 0.0080 & & \\
\hline ACQUISentry & & & & & $\begin{array}{c}2.135^{* *} \\
(1.95)\end{array}$ & 0.0094 & & \\
\hline $\begin{array}{l}\text { MNEentry• } \\
\text { dTFPlow }\end{array}$ & & & $\begin{array}{c}4.551 * * * \\
(2.56)\end{array}$ & 0.0198 & & & & \\
\hline dTFPlow & & & $\begin{array}{l}-0.066 \\
(-1.19)\end{array}$ & -0.0003 & & & & \\
\hline entry & $\begin{array}{l}0.007 \\
(0.01)\end{array}$ & 0.0000 & $\begin{array}{l}0.016 \\
(0.03)\end{array}$ & 0.0001 & $\begin{array}{l}0.023 \\
(0.05)\end{array}$ & 0.0001 & $\begin{array}{l}0.030 \\
(0.07) \\
\end{array}$ & 0.0001 \\
\hline hFDI & $\begin{array}{l}0.039 \\
(0.20)\end{array}$ & 0.0002 & $\begin{array}{c}2.134^{*} \\
(1.63) \\
\end{array}$ & 0.0093 & $\begin{array}{c}2.290^{*} \\
(1.76)\end{array}$ & 0.0100 & $\begin{array}{l}0.034 \\
(0.17)\end{array}$ & 0.0002 \\
\hline $\begin{array}{l}\text { hFDI. } \\
\text { lnWage }\end{array}$ & & & $\begin{array}{c}-0.349^{*} \\
(-1.79)\end{array}$ & -0.0015 & $\begin{array}{c}-0.375^{* *} \\
(-1.93)\end{array}$ & -0.0016 & & \\
\hline ReghFDI & $\begin{array}{l}0.129 \\
(0.47) \\
\end{array}$ & 0.0006 & $\begin{array}{l}0.237 \\
(0.79) \\
\end{array}$ & 0.0010 & $\begin{array}{l}0.202 \\
(0.68)\end{array}$ & 0.0009 & $\begin{array}{l}0.133 \\
(0.48) \\
\end{array}$ & 0.0006 \\
\hline BackFDI & $\begin{array}{l}1.980 \\
(1.27)\end{array}$ & 0.0090 & $\begin{array}{l}1.932 \\
(1.21)\end{array}$ & 0.0084 & $\begin{array}{l}1.979 \\
(1.24)\end{array}$ & 0.0087 & $\begin{array}{c}11.035^{* * *} \\
(2.95)\end{array}$ & 0.0494 \\
\hline $\begin{array}{l}\text { BackFDI· } \\
\text { lnWage }\end{array}$ & & & & & & & $\begin{array}{c}-1.229 * * * \\
(-2.86)\end{array}$ & -0.0055 \\
\hline BackConc & $\begin{array}{l}-6.560 \\
(-0.43)\end{array}$ & -0.0298 & $\begin{array}{l}-6.963 \\
(-0.43)\end{array}$ & -0.0302 & $\begin{array}{l}-6.103 \\
(-0.38)\end{array}$ & -0.0268 & $\begin{array}{l}-6.954 \\
(-0.44)\end{array}$ & -0.0311 \\
\hline ForFDI & $\begin{array}{l}-2.933^{*} \\
(-1.79)\end{array}$ & -0.0133 & $\begin{array}{c}-3.551^{* *} \\
(-2.10)\end{array}$ & -0.0154 & $\begin{array}{c}-3.644 * * \\
(-2.17)\end{array}$ & -0.0160 & $\begin{array}{l}-3.745 \\
(-0.54)\end{array}$ & -0.0168 \\
\hline $\begin{array}{l}\text { ForFDI· } \\
\text { lnWage }\end{array}$ & & & & & & & $\begin{array}{l}0.032 \\
(0.03)\end{array}$ & 0.0001 \\
\hline ForConc & $\begin{array}{l}-4.430 \\
(-0.31)\end{array}$ & -0.0201 & $\begin{array}{l}-2.144 \\
(-0.15)\end{array}$ & -0.0093 & $\begin{array}{l}-2.271 \\
(-0.16)\end{array}$ & -0.0100 & $\begin{array}{l}-2.489 \\
(-0.17)\end{array}$ & -0.0111 \\
\hline IMint & $\begin{array}{l}0.168 \\
(1.17)\end{array}$ & 0.0008 & $\begin{array}{l}0.072 \\
(0.46)\end{array}$ & 0.0003 & $\begin{array}{l}0.065 \\
(0.42)\end{array}$ & 0.0003 & $\begin{array}{l}0.174 \\
(1.20) \\
\end{array}$ & 0.0008 \\
\hline $\begin{array}{l}\text { Imint• } \\
\text { COMPL }\end{array}$ & & & $\begin{array}{l}1.192 * * \\
(2.26)\end{array}$ & 0.0052 & $\begin{array}{l}1.196 * * \\
(2.27)\end{array}$ & 0.0052 & & \\
\hline COMPL & & & $\begin{array}{l}-0.169 \\
(-1.10)\end{array}$ & -0.0007 & $\begin{array}{l}-0.171 \\
(-1.11)\end{array}$ & -0.0008 & & \\
\hline plants & $\begin{array}{c}-0.059^{* * *} \\
(-2.80)\end{array}$ & -0.0003 & $\begin{array}{c}-0.058^{* * *} \\
(-2.82)\end{array}$ & -0.0003 & $\begin{array}{c}-0.058^{* * *} \\
(-2.80)\end{array}$ & -0.0003 & $\begin{array}{c}-0.061^{* * *} \\
(-2.84)\end{array}$ & -0.0003 \\
\hline HHI & $\begin{array}{l}0.126 \\
(0.65)\end{array}$ & 0.0006 & $\begin{array}{l}0.222 \\
(1.16)\end{array}$ & 0.0010 & $\begin{array}{l}0.221 \\
(1.15)\end{array}$ & 0.0010 & $\begin{array}{l}0.128 \\
(0.66)\end{array}$ & 0.0006 \\
\hline dexport & $\begin{array}{l}-0.010 \\
(-0.23)\end{array}$ & 0.0000 & $\begin{array}{l}-0.012 \\
(-0.29)\end{array}$ & -0.0001 & $\begin{array}{l}-0.012 \\
(-0.28)\end{array}$ & -0.0001 & $\begin{array}{l}-0.010 \\
(-0.23)\end{array}$ & 0.0000 \\
\hline dexmajor & $\begin{array}{c}0.132^{* *} \\
(2.29)\end{array}$ & 0.0007 & $\begin{array}{c}0.132^{* *} \\
(2.27)\end{array}$ & 0.0007 & $\begin{array}{c}0.131 * * \\
(2.27)\end{array}$ & 0.0007 & $\begin{array}{c}0.132^{* *} \\
(2.28)\end{array}$ & 0.0007 \\
\hline dprofit & $\begin{array}{c}-0.375^{* * *} \\
(-6.15)\end{array}$ & -0.0033 & $\begin{array}{c}-0.373 * * * \\
(-6.11)\end{array}$ & -0.0032 & $\begin{array}{c}-0.370 * * * \\
(-6.07)\end{array}$ & -0.0032 & $\begin{array}{c}-0.371 * * * \\
(-6.08)\end{array}$ & -0.0032 \\
\hline fdi & $\begin{array}{l}0.030 \\
(0.37)\end{array}$ & 0.0001 & $\begin{array}{l}0.026 \\
(0.32)\end{array}$ & 0.0001 & $\begin{array}{l}0.025 \\
(0.30)\end{array}$ & 0.0001 & $\begin{array}{l}0.031 \\
(0.38)\end{array}$ & 0.0001 \\
\hline InEmpl & $\begin{array}{c}-0.670 * * * \\
(-9.05)\end{array}$ & -0.0044 & $\begin{array}{c}-0.666^{* * *} \\
(-8.95)\end{array}$ & -0.0042 & $\begin{array}{c}-0.664 * * * \\
(-8.98)\end{array}$ & -0.0043 & $\begin{array}{c}-0.673 * * * \\
(-9.02)\end{array}$ & -0.0044 \\
\hline
\end{tabular}




\begin{tabular}{|c|c|c|c|c|c|c|c|c|}
\hline lnEmpl2 & $\begin{array}{c}0.048^{* * *} \\
(3.18)\end{array}$ & 0.0002 & $\begin{array}{c}0.048^{* * * *} \\
(3.11)\end{array}$ & 0.0002 & $\begin{array}{c}0.048^{* * *} \\
(3.11)\end{array}$ & 0.0002 & $\begin{array}{c}0.048^{* * *} \\
(3.15)\end{array}$ & 0.0002 \\
\hline $\operatorname{lnTFP}$ & $\begin{array}{c}-0.220 * * * \\
(-4.17)\end{array}$ & -0.0010 & $\begin{array}{c}-0.228 * * * \\
(-3.75)\end{array}$ & -0.0010 & $\begin{array}{c}-0.219 * * * \\
(-4.13)\end{array}$ & -0.0010 & $\begin{array}{c}-0.219^{* * *} \\
(-4.15)\end{array}$ & -0.0010 \\
\hline InKint & $\begin{array}{c}-0.186^{* * *} \\
(-7.91)\end{array}$ & -0.0008 & $\begin{array}{c}-0.191 * * * \\
(-8.08)\end{array}$ & -0.0008 & $\begin{array}{c}-0.190 * * * \\
(-8.09)\end{array}$ & -0.0008 & $\begin{array}{c}-0.187 * * * \\
(-7.92)\end{array}$ & -0.0008 \\
\hline lnWage & $\begin{array}{c}-0.330 * * * \\
(-7.13)\end{array}$ & -0.0015 & $\begin{array}{c}-0.298 * * * \\
(-5.93)\end{array}$ & -0.0013 & $\begin{array}{c}-0.292 * * * \\
(-5.82)\end{array}$ & -0.0013 & $\begin{array}{c}-0.257^{* * *} \\
(-3.25)\end{array}$ & -0.0012 \\
\hline lnAge & $\begin{array}{l}-0.205 \\
(-1.10)\end{array}$ & -0.0009 & $\begin{array}{l}-0.239 \\
(-1.27)\end{array}$ & -0.0010 & $\begin{array}{l}-0.226 \\
(-1.21)\end{array}$ & -0.0010 & $\begin{array}{l}-0.213 \\
(-1.15)\end{array}$ & -0.0010 \\
\hline lnAge2 & $\begin{array}{c}1.416^{* * *} \\
(17.38)\end{array}$ & 0.0064 & $\begin{array}{c}1.439^{* * *} \\
(17.36)\end{array}$ & 0.0062 & $\begin{array}{c}1.430^{* * *} \\
(17.35)\end{array}$ & 0.0063 & $\begin{array}{c}1.422^{* * *} \\
(17.61)\end{array}$ & 0.0064 \\
\hline Cons & $\begin{array}{c}7.258^{* * * *} \\
(4.71) \\
\end{array}$ & & $\begin{array}{c}6.701 * * * \\
(4.23) \\
\end{array}$ & & $\begin{array}{c}6.582 * * * \\
(4.18) \\
\end{array}$ & & $\begin{array}{c}6.672^{* * *} \\
(4.19) \\
\end{array}$ & \\
\hline \multicolumn{9}{|c|}{ Wald's test for heteroscedasticity. $\mathrm{H}_{0}$ : Insigma2=0 } \\
\hline $\begin{array}{r}\text { Insigma2 } \\
\text { lempl }\end{array}$ & $\begin{array}{c}-0.128 * * * \\
(-6.35)\end{array}$ & & $\begin{array}{c}-0.129 * * * \\
(-6.43)\end{array}$ & & $\begin{array}{c}-0.130 * * * \\
(-6.49)\end{array}$ & & $\begin{array}{c}-0.127 * * * \\
(-6.26)\end{array}$ & \\
\hline $\begin{array}{l}\text { chi2(1) } \\
\text { (Prob>chi2) }\end{array}$ & $\begin{array}{l}40.310 \\
(0.000) \\
\end{array}$ & & $\begin{array}{l}41.300 \\
(0.000) \\
\end{array}$ & & $\begin{array}{l}42.090 \\
(0.000)\end{array}$ & & $\begin{array}{l}39.200 \\
(0.000)\end{array}$ & \\
\hline pseudo R2 & 47.2 & & 47.4 & & 47.3 & & 47.3 & \\
\hline $\begin{array}{l}\text { Log pseudo- } \\
\text { likelihood }\end{array}$ & -2583.253 & & -2560.287 & & -2563.256 & & -2579.002 & \\
\hline industry dummies & INCL & & INCL & & INCL & & INCL & \\
\hline time dummies & INCL & & INCL & & INCL & & INCL & \\
\hline regional dummies & INCL & & INCL & & INCL & & INCL & \\
\hline ownership dumm. & INCL & & INCL & & INCL & & INCL & \\
\hline $\mathbf{N}$ & 34272 & & 34042 & & 34042 & & 34272 & \\
\hline $\operatorname{Pr}(y=1)$ in sample & & 0.03233 & & 0.0324 & & 0.03237 & & 0.0323 \\
\hline $\begin{array}{l}\operatorname{Pr}(y=1) \text { mean of } \\
\text { model prediction }\end{array}$ & & 0.03236 & & 0.0324 & & 0.03242 & & 0.0324 \\
\hline $\begin{array}{l}\operatorname{Pr}(y=1) \text { predicted } \\
\text { at means }\end{array}$ & & 0.00106 & & 0.0010 & & 0.00102 & & 0.0010 \\
\hline
\end{tabular}

Notes: - t-statistics are in parentheses,

- Huber/White/sandwich estimator of variance

- for dummy variables marginal effect $\mathrm{dP} / \mathrm{dX}$ is for a discrete change from 0 to 1

- ***,**, * denotes significance at $1 \%, 5 \%$ and $10 \%$, respectively.

Source: own calculations

The above results provide strong support for the prediction that a foreign firm's entry stimulates the selection process among firms within the same industry based on their productive efficiency. More specifically, the selection process is characterised by the least efficient firms experiencing a drop in their survival probability upon a foreign firm's entry. On the other hand, more efficient and more skillintensive firms do not experience any pronounced 'static' crowding out and they have a higher ability to benefit in the long term from the foreign firms' presence. The significant difference between domestic and foreign entry in terms of their reallocation forces corresponds well to the theoretical predictions that foreign firms enter on a larger scale and tend to be above-average productive.

Distinguishing between greenfield entry and foreign firm entry through acquisition (Model 3, Table 5), I find that although the magnitude of the crowding-out effect of these two types of FDI is not significantly different according to the F-test, only the coefficient of the acquisition entry is confirmed as significant. This result contradicts the general conviction of greater crowding out being associated with greenfield entry. However, knowing from Tables 1-4 that acquisition entrants are larger and more productive than their greenfield counterparts and account for the majority of foreign firm entries, the 
result might not be that surprising. In addition, it can be argued that a foreign entry in the form of an acquisition has a more immediate effect on local firms compared to a greenfield entry.

Regarding inter-industry spillovers I find a significantly negative effect of a foreign firms' presence on the probability of local firms exiting through forward linkages, suggesting that the presence of foreign affiliates does reduce the exit probability of their downstream local customers. Positive forward spillover effects are still significant after controlling for the general concentration of economic activity in vertically-linked industries. According to the literature, local firms may benefit from their upstream foreign firm suppliers through several potential channels such as through the increased availability of inputs, through their qualitative improvement and/or price reduction etc. Interestingly, the beneficial effect on the price decline of intermediates is also emphasised as an important channel of increased foreign competition (through imports) in Bernard, Eaton, Jensen, and Kortum (2003)'s model simulations. However, more detailed data would be needed to test for these different channels.

On the other hand, there is no evidence that the presence of foreign firms would significantly affect the probability of shutting down their upstream local suppliers (through backward linkages). This result, at least at first sight, contradicts recent findings of positive productivity externalities connected to the extent of foreign firm presence through backward linkages for several transition countries (for instance, Damijan, Knell, Majcen, Rojec (2003) for Czech Republic, Poland and Slovenia, and Smarzynska (2004) for Lithuania). However, the studies mentioned above estimate vertical (backward) spillovers conditioned on the survival of domestic firms in the upstream industry and only consider larger firms with more than 10 employees which are less likely to exit the market. Taking into account findings on the positive effects of MNEs' presence in backwardly-linked industries on the productivity of surviving firms and their insignificant impact on the probability of surviving, it seems quite likely that some firms face an increased probability of exiting in response to the concentration of foreign firms in downstream industries (Model 4 suggests these are less skill-intensive firms), while the successful surviving firms are able to take advantage of the MNEs' presence in downstream industries through backward linkages. This leads us to suspect that the degree of linkages might be weaker in the case of MNEs compared to domestic firms, leading to a decrease in demand for intermediate products.

To test this argument further, I include interaction terms between vertical FDI concentration and absorptive capacity in the way I did for the horizontal spillover effects (Model 4, Table 5). Similarly, as confirmed for the intra-industry effects of FDI presence, both coefficients positive for BackFDI $\mathrm{j}_{\mathrm{jt}}$ and negative for its interaction with skill-intensity become significant. It appears that it is more likely that for firms which are relatively less skill-intensive a vertical crowding out would prevail over positive externalities, while for skilled intensive firms there is more scope for the net positive effect from vertical FDI concentration. The net impact is thus insignificant but there is evidence that the selection process induced by a foreign firm's entry and presence also takes place through backward linkages (vertical crowding out). Under the presence of vertical crowding out, those studies that do not control for the impact on the exit of local firms overestimate the degree of spillover effects from foreign to local firms through backward linkages. On the other hand, there is no evidence that absorptive capacity would play an important role in taking advantage of FDI concentration in forwardly-linked industries. The results suggest that the ability to benefit from the relationship with foreign suppliers is not systematically related to a firm's absorptive capacity.

Regarding the competition effect from increased imports, I find the positive but insignificant impact of import intensity in general on a firm's probability of exiting. The significant and positive interaction term, however, indicates that the import crowding-out effect increases with the degree of complementarity between foreign affiliates' sales in imports. 
The impacts of other standard variables in exit and growth models are in line with the theoretical predictions. Size, age and total factor productivity all have a negative effect on the probability of exiting and are all highly significant, with the exception of age. The second-order terms of size and age are both significantly positive, confirming the nonlinear relation between firm size (age) and the probability of exiting, and are in accordance with several other studies that also found the presence of their nonlinear size and age effects. Among other firm characteristics that affect the prospects of survival, as expected average wage, capital intensity and the profit dummy are found to reduce the probability of exiting which indicates the importance of the skill and capital intensity of the firm and its overall successfulness for the firm's survival.

The number of a firm's subsidiaries decreases the probability of exiting, which corresponds to the prediction that multi-plant firms have a lower probability of death compared to single-plant firms, with everything else being equal. Contrary to the theoretical expectations, there is no significant positive effect of being an exporter in terms of a lower probability of exiting. The probability of exiting is in fact greater for exporters that sell the majority of their output in foreign markets. The results suggest that firms with an export propensity above $70 \%$ are more vulnerable and more likely to shut down, everything else being equal, than exporters with a lower export propensity or firms oriented to the domestic market. The reason could be the greater exposure to higher external competition, as argued by Könings and Xavier (2002) who also found a negative effect of exporting status on firm survival for Slovenian manufacturing firms but in a different period. Another reason may be related to the fact that an important share of these 'majority exporters' involves firms that are contractors to foreign firms in, typically, labour-intensive industries that face increased international competition from lowwage countries. Regarding the effect of industry-specific factors, in most estimated versions of the exit model market concentration positively affects the probability of exiting although the coefficient is insignificant.

The estimates for the sub-sample of domestically-owned firms only (Appendix 1) confirm practically all the above derived conclusions from the full sample estimations. Further, it seems that the impact of FDI-related variables is even more pronounced and significant. The analysis of any difference between foreign and domestic firms with respect to the response to increased foreign firm activity follows.

\subsection{Correcting for endogeneity}

In all estimated versions of the exit model reported in Table 5, the coefficient of the $f d i_{i j t}$ dummy variable is positive but not significant so it cannot be concluded that foreign firms differ with respect to the exit probability from domestically-owned competitors after controlling for other determinants of the exit decision. However, as already pointed out in the previous section, foreign ownership might not be entirely exogenous particularly where foreign investors tend to acquire shares in the most successful, larger domestic firms. To deal with the problem of endogeneity, I instrument for the foreign ownership variable and estimate the instrumental variables probit by employing the two-stage method proposed by Newey (1987). I estimate three versions of the instrumental variables probit, and report the results in Table 6; in the first two versions (columns 1 and 2) I instrument for foreign ownership without distinguishing between different types of foreign investment, while in the third (column 3) I instrument for foreign ownership separately for acquisition and greenfield-type foreign investments. 
Table 6: Instrumental variables probit exit model estimates for the aggregate sample of foreign and domestic firms

\begin{tabular}{|c|c|c|c|}
\hline & Coef. & Coef. & Coef. \\
\hline & 1 & 2 & 3 \\
\hline fdi $^{\text {INS }}$ & $0.914 * * *(4.49)$ & $0.934 * * *(4.63)$ & \\
\hline fdi (acquisitions) ${ }^{\text {INS }}$ & & & $0.710 * * *(3.71)$ \\
\hline fdi (greenfield) ${ }^{\text {INS }}$ & & & $-0.175(-0.41)$ \\
\hline MNEentry & $3.371 * * *(2.47)$ & $1.361(0.82)$ & $2.066(1.2)$ \\
\hline MNEentry•dTFPlow & & $7.086^{* * *}(2.94)$ & $5.307 * *(2.1)$ \\
\hline dTFPlow & & $-0.159 * *(-2.19)$ & $-0.132 *(-1.78)$ \\
\hline entry & $0.497(0.72)$ & $0.467(0.67)$ & $0.641(0.88)$ \\
\hline hFDI & $0.212(0.76)$ & $4.513 * *(2.44)$ & $5.187 * * *(2.68)$ \\
\hline hFDI·lnWage & & $-0.672 * * *(-2.52)$ & $-0.787 * * *(-2.83)$ \\
\hline ReghFDI & $-0.361(-0.72)$ & $-0.196(-0.39)$ & $-0.201(-0.39)$ \\
\hline BackFDI & $5.070 * *(2.24)$ & $4.978 * *(2.16)$ & $5.762 * *(2.43)$ \\
\hline BackConc & $-25.375(-1.08)$ & $-26.738(-1.11)$ & $-25.546(-1.05)$ \\
\hline ForFDI & $-5.676 * *(-2.39)$ & $-6.532 * * *(-2.71)$ & $-6.256 * * *(-2.54)$ \\
\hline ForConc & $-4.004(-0.2)$ & $0.198(0.01)$ & $-5.698(-0.28)$ \\
\hline IMint & $0.204(0.88)$ & $0.176(0.68)$ & $0.157(0.6)$ \\
\hline Imint·COMPL & & $1.130(1.56)$ & $1.179(1.59)$ \\
\hline COMPL & & $-0.106(-0.5)$ & $-0.082(-0.38)$ \\
\hline plants & $-0.108 * * *(-3.15)$ & $-0.109 * * *(-3.16)$ & $-0.116 * * *(-3.27)$ \\
\hline HHI & $0.187(0.7)$ & $0.292(1.07)$ & $0.378(1.39)$ \\
\hline dexport & $-0.075(-1.28)$ & $-0.080(-1.36)$ & $-0.063(-1.05)$ \\
\hline dexmajor & $0.014(0.15)$ & $0.007(0.08)$ & $0.063(0.65)$ \\
\hline dprofit & $-0.460 * * *(-6.13)$ & $-0.466 * * *(-6.19)$ & $-0.445 * * *(-5.82)$ \\
\hline InEmpl & $-1.043 * * *(-13.16)$ & $-1.052 * * *(-13.22)$ & $-1.064 * * *(-13.21)$ \\
\hline lnEmpl2 & $0.071 * * *(3.45)$ & $0.072 * * *(3.48)$ & $0.074 * * *(3.55)$ \\
\hline InTFP & $-0.308 * * *(-5.47)$ & $-0.349 * * *(-5.48)$ & $-0.347 * * *(-5.39)$ \\
\hline lnKint & $-0.251 * * *(-8.34)$ & $-0.254 * * *(-8.4)$ & $-0.257 * * *(-8.35)$ \\
\hline lnWage & $-0.426 * * *(-8.18)$ & $-0.371 * * *(-6.38)$ & $-0.358(-6.06)$ \\
\hline lnAge & $-4.405 * * *(-9.19)$ & $-4.453 * * *(-9.24)$ & $-4.427 * * *(-9.07)$ \\
\hline lnAge2 & $2.956 * * *(19.73)$ & $2.986 * * *(19.82)$ & $2.998 * * *(19.56)$ \\
\hline Cons & $10.272 * * *(4.62)$ & $9.622 * * *(4.16)$ & $8.719 * * *(3.59)$ \\
\hline Hausman-Wu test (Chi2(1)) & $23.845^{* * *}$ & & \\
\hline Log pseudo-likelihood & -1959.327 & -1946.924 & -1899.125 \\
\hline sectoral dummies & INCL & INCL & INCL \\
\hline time dummies & INCL & INCL & INCL \\
\hline regional dummies & INCL & INCL & INCL \\
\hline ownership type dummies & INCL & INCL & INCL \\
\hline $\mathbf{N}$ & 30063 & 30006 & 30101 \\
\hline
\end{tabular}

Notes: - t-statistics are in parentheses,

- INS denotes instrumented,

- Huber/White/sandwich estimator of variance,

- $* * *, * *, *$ denotes significance at $1 \%, 5 \%$ and $10 \%$, respectively.

Source: own calculations

The intuition of the downward bias in the estimated coefficient of foreign ownership dummy in the previous estimates is confirmed. It appears that, when instrumented, foreign ownership significantly positively affects the probability of exiting (columns 1 and 2, Table 6), but this influence is not 
uniform for the two different types of foreign investment. According to column 3 in the model, only foreign ownership in the form of an acquisition is associated with a greater probability of exiting compared to other firms, while there is no evidence of a significant impact for a greenfield investment. The endogeneity of the foreign ownership variable seems to be confirmed in our estimates from the aggregate sample as the Hausman-Wu test rejects the null hypothesis of exogeneity at a negligible risk. This finding is in line with those of Görg and Strobl (2003) and Bernard and Jensen (2002) who also confirm that foreign plants have higher hazards of exiting than indigenous plants.

Turning to the estimated coefficients for the other variables, the IV probit results from Table 6 support previous estimates both with respect to the significance and relative magnitude of the estimated coefficients with the exception that in the IV probit estimates the positive impact of BackFDI $\mathrm{j}_{\mathrm{jt}}$ on the probability of exiting and the negative impact of age becomes significant, while the influence of being a 'majority' exporter and the positive coefficient of the interaction term between import intensity and degree of import-foreign affiliates sales overlapping are no longer significant. The main difference thus appears to be with respect to the increased probability of exiting in response to the concentration of foreign firms in downstream industries which provides additional support for the presence of vertical crowding out taking place through backward linkages between foreign firms and their local suppliers.

It has to be stressed that the IV probit's results crucially depend on the appropriateness (exogeneity) and quality of instruments used in the first step of the estimator. Besides, there is another issue that needs to be taken into account, namely the possibility that various factors affect the probability of exiting of domestic and foreign firms differently. Since the IV approach assumes that coefficients on the X's (independent variables) are restricted to be the same for foreign and domestic firms I also estimate Heckman's maximum-likelihood probit selection correction model (endogenous switching regime model). I split the sample into foreign and domestic firms and then estimate the exit model for each sub-sample correcting for the fact that the sub-samples are non-random samples of all firms (Table 7).

The estimates for the sub-sample of domestic firms (Table 7, column 1), corrected for selection bias which is according to Wald's test significant at $1 \%$, generally support previous estimates based on a heteroscedastic probit model for domestic firms only (Appendix 1) with respect to the significance and magnitude of the estimated coefficients. The exception is, similarly with the IV probit estimates (Table 6), that the increased concentration of foreign firms in downstream industries significantly increases the probability of exiting and that the negative impact of age on the probability of exiting becomes significant. Further, the conclusion is confirmed from the basic estimates that a foreign firm's entry in the form of an acquisition has a more significant crowding-out effect on domestic firms compared to greenfield investments .

Table 7: Heckman's selection correction exit model for foreign and domestic firms

\begin{tabular}{|l||c|c||c|}
\hline \multicolumn{1}{|l||}{ (Coef.) } & Domestic firms & Domestic firms & Foreign firms \\
\hline & $\mathbf{1}$ & $\mathbf{2}$ & $\mathbf{3}$ \\
\hline \hline MNEentry & $2.029(1.38)$ & & $-10.593(-1.07)$ \\
\hline GREENentry & & $2.216(1.12)$ & \\
\hline ACQUISentry & & $3.843^{* * *}(2.68)$ & \\
\hline MNEentry•dTFPlow & $5.858^{* * *}(2.47)$ & & $-12.540(-0.55)$ \\
\hline dTFPlow & $-0.111(-1.5)$ & & $-0.253(-0.59)$ \\
\hline entry & $0.564(0.9)$ & $0.612(0.98)$ & $3.512(1.12)$ \\
\hline hFDI & $3.295(1.58)$ & $0.180(0.75)$ & $-16.134(-1.18)$ \\
\hline
\end{tabular}




\begin{tabular}{|c|c|c|c|}
\hline hFDI·InWage & $-0.523 *(-1.68)$ & & $1.813(0.96)$ \\
\hline ReghFDI & $-0.128(-0.27)$ & $-0.179(-0.41)$ & $-2.970(-1.03)$ \\
\hline BackFDI & $5.944 * * *(2.69)$ & $5.351 * * *(2.53)$ & $5.775(0.62)$ \\
\hline BackConc & $-2.942(-0.12)$ & $6.642(0.29)$ & $-53.827(-0.58)$ \\
\hline ForFDI & $-7.580 * * *(-3.21)$ & $-6.778 * * *(-2.97)$ & $10.544(0.82)$ \\
\hline ForConc & $-8.988(-0.45)$ & $-14.890(-0.76)$ & $-30.526(-0.36)$ \\
\hline IMint & $0.082(0.55)$ & $0.123(0.89)$ & $-1.451(-1.44)$ \\
\hline Imint $\cdot \mathrm{COMPL}$ & $1.284 *(1.88)$ & & $9.693 * *(2.39)$ \\
\hline COMPL & $0.015(0.08)$ & & $-2.686^{* *}(-2.29)$ \\
\hline plants & $-0.102 * * *(-3.3)$ & $-0.101 * * *(-3.33)$ & $-4.584 * * *(-3.01)$ \\
\hline HHI & $0.367(1.5)$ & $0.167(0.69)$ & $2.160(1.56)$ \\
\hline dexport & $-0.059(-1.04)$ & $-0.055(-0.98)$ & $-0.369(-1.11)$ \\
\hline dexmajor & $0.149 *(1.78)$ & $0.142 *(1.72)$ & $1.016^{* * *}(2.9)$ \\
\hline dprofit & $-0.435 * * *(-5.25)$ & $-0.444 * * *(-5.38)$ & $-2.126 * * *(-4.51)$ \\
\hline InEmpl & $-0.939 * * *(-7.09)$ & $-0.941 * * *(-7.21)$ & $-1.392 * * *(-3.19)$ \\
\hline InEmpl2 & $0.044(1.31)$ & $0.047(1.43)$ & $0.097(1.08)$ \\
\hline InTFP & $-0.285 * * *(-3.62)$ & $-0.261 * * *(-3.83)$ & $-1.118 * * *(-3)$ \\
\hline InKint & $-0.277 * * *(-8.98)$ & $-0.267 * * *(-8.74)$ & $-0.463 * * *(-2.77)$ \\
\hline lnWage & $-0.411 * * *(-5.81)$ & $-0.456 * * *(-7.18)$ & $-0.302(-0.79)$ \\
\hline InAge & $-4.392 * * *(-8)$ & $-4.302 * * *(-8)$ & $-11.956 * * *(-4.51)$ \\
\hline InAge2 & $2.961 * * *(15.06)$ & $2.907 * * *(15.18)$ & $6.323 * * *(5.53)$ \\
\hline Cons & $6.883 * * *(3.45)$ & $6.963 * * *(3.61)$ & $-8.971(-0.72)$ \\
\hline 1. STAGE SELECTION & domestic & domestic & fdi \\
\hline domesticlag/fdilag & $4.005^{* * *}(47.49)$ & $4.006^{* * *}(47.49)$ & $4.003 * * *(47.87)$ \\
\hline InEmpllag & $-0.085 * * *(-5.5)$ & $-0.085 * * *(-5.49)$ & $0.094 * * *(5.65)$ \\
\hline InAgelag & $0.579 * * *(6.02)$ & $0.581 * * *(6.04)$ & $-0.685 * * *(-7.44)$ \\
\hline InAge2lag & $-0.116 * * *(-3.55)$ & $-0.116 * * *(-3.56)$ & $0.148 * * *(4.51)$ \\
\hline profitsaleslag & $-0.013 * * *(-3.41)$ & $-0.013 * * *(-3.41)$ & $0.013 * * *(3.98)$ \\
\hline Exproplag & $-0.708 * * *(-9.06)$ & $-0.707 * * *(-9.07)$ & $0.690 * * *(8.76)$ \\
\hline InTFPlag & $0.356 * * *(7.11)$ & $0.356 * * *(7.13)$ & $-0.390 * * *(-8.24)$ \\
\hline InWagelag & $-0.106^{* * *}(-14.37)$ & $-0.106 * * *(-14.36)$ & $0.102 * * *(13.6)$ \\
\hline cons & $-3.064 * * *(-13.05)$ & $-3.068 * * *(-13.09)$ & $-0.727 * * *(-3.6)$ \\
\hline \multicolumn{4}{|c|}{ Wald's test of independent equations $\left(\mathrm{H}_{0}:\right.$ rho $\left.=0\right)$} \\
\hline Athrho & $0.299 * * *(2.72)$ & $0.285 * * *(2.67)$ & $0.110(0.35)$ \\
\hline rho & 0.291 & 0.277 & 0.110 \\
\hline chi2(1) (Prob>chi2) & $7.4 * * *(0.006)$ & $7.100 * * *(0.008)$ & $0.100(0.728)$ \\
\hline Log pseudo-likelihood & -3453.9 & -3479.360 & -1593.621 \\
\hline industry dummies & INCL & INCL & INCL \\
\hline time dummies & INCL & INCL & INCL \\
\hline $\mathbf{N}$ (uncensored) & $30412(28524)$ & $30590(28702)$ & $31271(1866)$ \\
\hline
\end{tabular}

Notes: - t-statistics are in parentheses, Huber/White/sandwich estimator of variance, $* * *, * *, *$ denotes significance at $1 \%$, $5 \%$ and $10 \%$, respectively.

Source: own calculations

The results for the foreign firm sub-sample corrected for selection bias ${ }^{11}$ suggest that some factors considered in the model affect the probability of foreign firms exiting differently than in the case of domestic firms. It appears that the average wage has a insignificant impact on the probability of foreign firms exiting which is probably due to the greater multicollinearity of this variable with total factor productivity compared to the domestic firm sub-sample, while the impact of other firm characteristics is similar as for domestic firms; that is size, age, total factor productivity, capital

\footnotetext{
${ }^{11}$ According to Wald's test, the independence of the exit and selection equation cannot be rejected.
} 
intensity, profitability and number of subsidiaries negatively affect the probability of exiting and there is evidence of non-linear effects only for the age variable. Regarding the crowding-out effect and spillovers from the entry and presence of other foreign firms, there is no evidence of either crowdingout or spillover effects from foreign firms to other foreign firms. On the other hand, the intuition for the crowding-out effect of imports is similar as in the case of domestic firms but with a higher responsiveness to the degree of complementarity between imports and foreign firm sales.

The selection equation in the first stage of Heckman's probit selection correction model (Table 7, column 3) indicates that MNEs tend to acquire shares in domestic firms that are larger, younger, have a higher export propensity and a higher ratio of profits to sales, and are more skill-intensive (pay higher average wages), while the incidence of being acquired by a foreign investor is negatively related to total factor productivity. Thus, our hypothesis that foreign owners invest in more efficient local firms is not entirely confirmed. These conclusions are partially in line with previous studies on the determinants of FDI selection for a sample of Slovenian manufacturing firms. Damijan et al. (2003) found for a sample of firms with more than 10 employees that the probability of a foreign investment decision is positively related to the skill intensity of a firm, while capital intensity, labour productivity and size have an insignificant effect.

Based on the IV probit's estimates, conclusions from the basic heteroscedastic probit estimates about the impact of foreign firms' entry and presence on the probability of exiting of local (domestic) firms seem to be robust after controlling for the potential endogeneity of the foreign ownership variable. Further, there is additional evidence that the concentration of foreign firms in downstream industries (through backward linkages) has a negative net impact on the probability of surviving for domestic firms.

\section{Conclusions}

In the paper I test several theoretical predictions on inward FDI's impacts on a domestic firm's exit decision. I estimate different empirical specifications of the exit probit model using annual panel data on Slovenian manufacturing firms for the 1994-2003 period and controlling for several of the econometric problems involved.

The theoretically predicted channels through which inward FDI affects firm selection processes in a host country prove to be mostly significant for the Slovenian manufacturing sector in the last decade. First, there is evidence of the direct impact of foreign firms on a change in the population of firms in

Slovenia's manufacturing sector. Not only do foreign entrants tend to be above-average productive but they also differ from their domestic rivals with respect to the ease of exit. Foreign-owned firms find it easier to exit (particularly those entering in the form of acquisitions), confirming that they are on average more mobile than their domestic counterparts.

Second, the entry of foreign firms stimulates the selection process and reallocation of resources among firms within the same industry based on their productive efficiency. The firm selection process is, namely, characterised by the least efficient firms experiencing a drop in their survival probability upon a foreign firm's entry. More specifically, I find that if the foreign firm entry rate increases by one structural point the exit probability increases on average by $8.7 \%$, while for the least efficient firms the exit probability rises by almost $24 \%$. On the other hand, more efficient and more skill-intensive firms do not experience any pronounced 'static' crowding out with respect to the increased probability to exit. In addition, a foreign firm's entry seems to stimulate the selection process not only within the 
industry but also through backward linkages in the upstream supplying industries as indicated by less skill-intensive firms' increased probability of exiting when the concentration of foreign firm activity in backwardly-linked industries increases.

Third, regarding the productivity spillover effects from foreign to local firms the results suggest that they mostly operate through vertical linkages rather than within the same industry. The positive impact of foreign firms' activity on the survival probability through forward linkages with local customers is the most pronounced, while there is a higher probability of local firms exiting that is associated with the concentration of foreign firms in backwardly-linked industries. In general, it seems that not all firms are able to equally benefit from a foreign firm's presence and that their absorptive capacity plays an important role. 


\section{References}

Aitken, B., Harrison, A.E. (1999) "Do Domestic Firms Benefit from Direct Foreign Investment? Evidence from Venezuela", American Economic Review, Vol. 89, No 3, pp. 605-617.

Barrios, S., Görg, H., Strobl, E. (2005) "Foreign direct investment, competition and industrial development in the host country", European Economic Review, Vol. 49, No 7, pp. 1761-1784.

Bernard, A.B., Jensen, B.J. (2002) The Deaths of Manufacturing Plants, National Bureau of Economic Research, Cambridge, Mass., Working paper 9026, 47 p.

Bernard, A.B., Eaton, J., Jensen, B.J., Kortum, S. (2003) "Plants and Productivity in International Trade", American Economic Review, Vol. 93, pp. 1268-1290.

Blomström, M., Kokko, A. (1997) The Impact of Foreign Investment on Host Countries: A Review of the Empirical Evidence, The World Bank, Washington, Policy Research Working Paper 1745, 42 p.

Blomström, M., Kokko, A. (1998) "Multinational corporations and spillovers", Journal of Economic Surveys, Vol. 12, No 3, pp. 247-277.

Caves, R.E. (1996) Multinational Enterprise and Economic Analysis, Cambridge: Cambridge University Press.

Chamberlain, G. (1984) Panel Data, in Griliches, Z., Intriligator, M. D., eds., Handbook of Econometrics, Vol. 2, Amsterdam : North-Holland, pp. 1248-1318.

Damijan, J.P., Knell, M., Majcen, B., Rojec, M. (2003) Technology Transfer through FDI in Top-10 Transition Countries: How Important are Direct Effects, Horizontal and Vertical Spillovers?, William Davidson Institute, Working paper 549, $23 \mathrm{p}$.

De Backer, K., Sleuwaegen, L. (2003) "Does Foreign Direct Investment Crowd out Domestic Entrepreneurship?”, Review of Industrial Organization, Vol. 22, No 1, pp. 67-84.

Djankov, S., Hoekman, B. (2000) "Foreign Investment Productivity Growth in Czech Enterprises", World Bank Economic Review, Vol. 14, pp. 49-64.

Ericson, R., Pakes, A. (1995) "Markov-Perfect Industry Dynamics: A Framework for Empirical Work", Review of Economic Studies, Vol. 62, No 1, pp. 53-82.

Evans, D.S. (1987) “The Relationship between Firm Growth, Size, and Age: Estimates for 100 Manufacturing Industries”, Journal of Industrial Economics, Vol. 35, pp. 567-581.

Evenett, S.J., Voicu, A. (2001) Picking Winners or Creating Them? Revisiting the Benefits of FDI in the Czech Republic?, Washington: The World Bank, Mimeo.

Görg, H., Strobl, E. (2003) "Multinational Companies, Technology Spillovers and Plant Survival”, Scandinavian Journal of Economics, Vol. 105, No 4, pp.581-595.

Hall, B.H. (1987) "The Relationship between Firm Size and Firm Growth in the US Manufacturing Sector", Journal of Industrial Economics, Vol. 35, pp. 583-600.

Harvey, A.C. (1976) "Estimating Regression Models with Multiplicative Heteroscedasticity", Econometrica, Vol. 44, pp. 461-465.

Jovanović, B. (1982) “Selection and the Evolution of Industry”, Econometrica, Vol. 50, No 3, pp. 649-670. 
Keller, W., Yeaple, S. (2003) Multinational Enterprises, International Trade, and Productivity Growth: FirmLevel Evidence from the United States, University of Nottingham : GEP Research Paper, No 3.

Konings, J., Xavier, A. (2002) Firm Growth and Survival in a Transition Country: Micro Evidence from Slovenia., Katholieke Universiteit Leuven, LICOS Discussion paper 11402.

Kosová, R. (2004) Do Foreign Firms Crowd Out Domestic Firms? The Evidence from the Czech Republic, Ph.D. Thesis, University of Michigan Business School. Available from: $<$ http://www.london.edu/assets/documents/PDF/paper_Kosova.pdf] $>$ [Accessed October 5, 2005]

Levinsohn, J.A., Petrin, A. (2003) "Estimating Production Functions Using Inputs to Control for Unobservables", The Review of Economic Studies, Vol. 70, No. 2, pp. 317-341.

Mata, J., Portugal, P. (2004) "Patterns of Entry, Post-Entry Growth and Survival", Small Business Economics, Vol. 22, No 3-4, pp.283-298.

Melitz, M. (2003) "The Impact of Trade on Intra-Industry Reallocations and Aggregate Industry Productivity", Econometrica, Vol. 71, No 6, pp. 1695-1726.

Mundlak, Y. (1978) "On the Pooling of Time Series and Cross Section Data", Econometrica, Vol. 46, No 1, pp. 69-85.

Newey, W.K. (1987) "Efficient Estimation of Limited Dependent Variable Models with Endogenous Explanatory Variables", Journal of Econometrics, Vol. 36, pp. 231-250.

Olley, S., Pakes, A. (1996) "The dynamics of productivity in the telecommunications equipment industry", Econometrica, Vol. 64, pp. 1263-1297.

Pavcnik, N. (2002) “Trade Liberalization, Exit, and Productivity Improvements: Evidence from Chilean Plants", The Review of Economic Studies, Vol. 69, pp. 245-276.

Rivera-Batiz, F., Rivera-Batiz, L. (1991) "The effects of direct foreign direct investment in the presence of increasing returns due to specialization”, Journal of Development Economics, Vol. 34, No 1-2, pp. 287-307.

Roberts, M.J., Tybout, J.R. (1996) Industrial Evolution in Developing Countries: Micro Patters of Turnover, Productivity, and Market Structure, Oxford: Oxford University Press.

Saggi, K. (2002) "Trade, Foreign Direct Investment, and International Technology Transfer: A Survey", The World Bank Research Observer, Vol. 17, No 2, pp. 191-235.

Smarzynska, J.B. (2004) "Does Foreign Direct Investment Increase the Productivity of Domestic Firms? In Search of Spillovers through Backward Linkages", American Economic Review, Vol. 94, No 3, pp. 605-627.

Sutton, J. (1997) “Gibrat's Legacy”, Journal of Economic Literature, Vol. 35, No 1, pp. 40-59.

Tybout, J.R. (2001) Plant and Firm-Level Evidence on New Trade Theories, National Bureau of Economic Research, Cambridge, Mass., Working Paper 8418.

Wooldridge, J.M. (2002) Econometric Analysis of Cross Section and Panel Data, Cambridge, Mass.: The MIT Press, $752 \mathrm{p}$. 


\section{Appendix 1: Heteroscedastic probit exit model estimates for the sub-sample of domestic firms}

\begin{tabular}{|c|c|c|c|c|c|c|c|c|}
\hline & Coef. & $\begin{array}{c}\text { marginal } \\
\text { effects } \\
\text { dP/dX }\end{array}$ & Coef. & 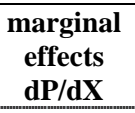 & Coef. & $\begin{array}{c}\text { marginal } \\
\text { effects } \\
\text { dP/dX }\end{array}$ & Coef. & $\begin{array}{c}\text { marginal } \\
\text { effects } \\
\text { dP/dX }\end{array}$ \\
\hline & 1 & 1 & 2 & 2 & 3 & 3 & 4 & 4 \\
\hline MNEentry & $\begin{array}{c}2.354 * * \\
(2.39)\end{array}$ & 0.0107 & $\begin{array}{l}1.035 \\
(0.92)\end{array}$ & 0.0044 & & & & \\
\hline GREENentry & & & & & $\begin{array}{l}1.243 \\
(0.74) \\
\end{array}$ & 0.0054 & $\begin{array}{l}1.260 \\
(0.75)\end{array}$ & 0.0054 \\
\hline ACQUISentry & & & & & $\begin{array}{c}2.788^{* *} \\
(2.4) \\
\end{array}$ & 0.0121 & $\begin{array}{c}2.776^{* * *} \\
(2.42) \\
\end{array}$ & 0.0120 \\
\hline $\begin{array}{l}\text { MNEentry } \\
\text { dTFPlow }\end{array}$ & & & $\begin{array}{c}5.218 * * * \\
(2.88)\end{array}$ & 0.0224 & & & & \\
\hline dTFPlow & & & $\begin{array}{l}-0.086 \\
(-1.51)\end{array}$ & -0.0003 & & & & \\
\hline entry & $\begin{array}{c}-0.092 \\
(-0.2)\end{array}$ & -0.0004 & $\begin{array}{l}-0.084 \\
(-0.18)\end{array}$ & -0.0004 & $\begin{array}{c}-0.046 \\
(-0.1)\end{array}$ & -0.0002 & $\begin{array}{l}-0.065 \\
(-0.14) \\
\end{array}$ & -0.0003 \\
\hline hFDI & $\begin{array}{l}0.025 \\
(0.12)\end{array}$ & 0.0001 & $\begin{array}{l}2.451^{*} \\
(1.87)\end{array}$ & 0.0105 & $\begin{array}{c}2.612^{* *} \\
(2.01)\end{array}$ & 0.0113 & $\begin{array}{l}1.206 \\
(0.82)\end{array}$ & 0.0052 \\
\hline hFDI· InWage & & & $\begin{array}{c}-0.401 * * \\
(-2.02)\end{array}$ & -0.0017 & $\begin{array}{c}-0.429^{* *} \\
(-2.18)\end{array}$ & -0.0019 & $\begin{array}{l}-0.222 \\
(-1.01)\end{array}$ & -0.0010 \\
\hline ReghFDI & $\begin{array}{l}0.198 \\
(0.71)\end{array}$ & 0.0009 & $\begin{array}{l}0.334 \\
(1.09)\end{array}$ & 0.0014 & $\begin{array}{l}0.293 \\
(0.98)\end{array}$ & 0.0013 & $\begin{array}{l}0.260 \\
(0.88)\end{array}$ & 0.0011 \\
\hline BackFDI & $\begin{array}{c}2.058 \\
(1.3)\end{array}$ & 0.0093 & $\begin{array}{l}1.956 \\
(1.2)\end{array}$ & 0.0084 & $\begin{array}{l}1.996 \\
(1.24) \\
\end{array}$ & 0.0087 & $\begin{array}{c}8.660^{* *} \\
(2.16)\end{array}$ & 0.0373 \\
\hline BackFDI·InWage & & & & & & & $\begin{array}{c}-0.929^{* *} \\
(-1.93)\end{array}$ & -0.0040 \\
\hline BackConc & $\begin{array}{l}-10.197 \\
(-0.63)\end{array}$ & -0.0462 & $\begin{array}{c}-11.661 \\
(-0.68) \\
\end{array}$ & -0.0501 & $\begin{array}{r}-10.505 \\
(-0.62) \\
\end{array}$ & -0.0455 & $\begin{array}{r}-11.305 \\
(-0.66) \\
\end{array}$ & -0.0488 \\
\hline ForFDI & $\begin{array}{c}-3.048^{*} \\
(-1.8)\end{array}$ & -0.0138 & $\begin{array}{c}-3.652 * * \\
(-2.09)\end{array}$ & -0.0157 & $\begin{array}{c}-3.781^{* *} \\
(-2.17)\end{array}$ & -0.0164 & $\begin{array}{l}-1.111 \\
(-0.16) \\
\end{array}$ & -0.0048 \\
\hline ForFDI·lnWage & & & & & & & $\begin{array}{l}-0.421 \\
(-0.43)\end{array}$ & -0.0018 \\
\hline ForConc & $\begin{array}{l}-1.425 \\
(-0.1)\end{array}$ & -0.0065 & $\begin{array}{l}2.112 \\
(0.14)\end{array}$ & 0.0091 & $\begin{array}{l}2.040 \\
(0.14)\end{array}$ & 0.0088 & $\begin{array}{l}3.846 \\
(0.26)\end{array}$ & 0.0166 \\
\hline IMint & $\begin{array}{l}0.153 \\
(1.03)\end{array}$ & 0.0007 & $\begin{array}{l}0.059 \\
(0.37)\end{array}$ & 0.0003 & $\begin{array}{l}0.047 \\
(0.29)\end{array}$ & 0.0002 & $\begin{array}{l}0.058 \\
(0.36)\end{array}$ & 0.0003 \\
\hline Imint·COMPL & & & $\begin{array}{c}1.273^{* *} \\
(2.29)\end{array}$ & 0.0055 & $\begin{array}{c}1.268^{* *} \\
(2.3)\end{array}$ & 0.0055 & $\begin{array}{c}1.276^{* *} \\
(2.33)\end{array}$ & 0.0055 \\
\hline COMPL & & & $\begin{array}{l}-0.193 \\
(-1.23)\end{array}$ & -0.0008 & $\begin{array}{l}-0.193 \\
(-1.23)\end{array}$ & -0.0008 & $\begin{array}{l}-0.186 \\
(-1.18)\end{array}$ & -0.0008 \\
\hline plants & $\begin{array}{c}-0.052 * * * \\
(-2.58)\end{array}$ & -0.0002 & $\begin{array}{c}-0.052^{* * *} \\
(-2.61)\end{array}$ & -0.0002 & $\begin{array}{c}-0.051^{* * * *} \\
(-2.6)\end{array}$ & -0.0002 & $\begin{array}{c}-0.053^{* * * *} \\
(-2.65)\end{array}$ & -0.0002 \\
\hline HHI & $\begin{array}{l}0.109 \\
(0.56)\end{array}$ & 0.0005 & $\begin{array}{l}0.204 \\
(1.06)\end{array}$ & 0.0009 & $\begin{array}{l}0.201 \\
(1.04) \\
\end{array}$ & 0.0009 & $\begin{array}{l}0.202 \\
(1.05)\end{array}$ & 0.0009 \\
\hline dexport & $\begin{array}{l}0.001 \\
(0.02)\end{array}$ & 0.0000 & $\begin{array}{l}-0.002 \\
(-0.04)\end{array}$ & 0.0000 & $\begin{array}{l}-0.001 \\
(-0.02) \\
\end{array}$ & 0.0000 & $\begin{array}{l}-0.001 \\
(-0.01)\end{array}$ & 0.0000 \\
\hline dexmajor & $\begin{array}{l}0.117^{*} \\
(1.91)\end{array}$ & 0.0006 & $\begin{array}{l}0.115^{*} \\
(1.85)\end{array}$ & 0.0006 & $\begin{array}{c}0.112^{*} \\
(1.8)\end{array}$ & 0.0006 & $\begin{array}{l}0.111^{*} \\
(1.79)\end{array}$ & 0.0006 \\
\hline dprofit & $\begin{array}{c}-0.347 * * * \\
(-5.55)\end{array}$ & -0.0029 & $\begin{array}{c}-0.345^{* * *} \\
(-5.49)\end{array}$ & -0.0028 & $\begin{array}{c}-0.341^{* * *} \\
(-5.45) \\
\end{array}$ & -0.0027 & $\begin{array}{c}-0.338 * * * \\
(-5.39) \\
\end{array}$ & -0.0027 \\
\hline lnEmpl & $\begin{array}{c}-0.660 * * * \\
(-8.69)\end{array}$ & -0.0045 & $\begin{array}{c}-0.655^{* * *} \\
(-8.59)\end{array}$ & -0.0042 & $\begin{array}{c}-0.652 * * * \\
(-8.58)\end{array}$ & -0.0043 & $\begin{array}{c}-0.651 * * * \\
(-8.52)\end{array}$ & -0.0042 \\
\hline $\operatorname{lnEmpl2}$ & $\begin{array}{c}0.048^{* * * *} \\
(3.22)\end{array}$ & 0.0002 & $\begin{array}{c}0.048^{* * *} \\
(3.16)\end{array}$ & 0.0002 & $\begin{array}{c}0.048^{* * *} \\
(3.17)\end{array}$ & 0.0002 & $\begin{array}{c}0.048^{* * *} \\
(3.13)\end{array}$ & 0.0002 \\
\hline InTFP & $\begin{array}{c}-0.203 * * * \\
(-3.77)\end{array}$ & -0.0009 & $\begin{array}{c}-0.219^{* * *} \\
(-3.51)\end{array}$ & -0.0009 & $\begin{array}{c}-0.203^{* * *} \\
(-3.75)\end{array}$ & -0.0009 & $\begin{array}{c}-0.201^{* * *} \\
(-3.73)\end{array}$ & -0.0009 \\
\hline InKint & $\begin{array}{c}-0.190 * * * \\
(-8.00)\end{array}$ & -0.0009 & $\begin{array}{c}-0.194 * * * \\
(-8.11)\end{array}$ & -0.0008 & $\begin{array}{c}-0.193^{* * *} \\
(-8.09)\end{array}$ & -0.0008 & $\begin{array}{c}-0.193^{* * *} \\
(-8.08)\end{array}$ & -0.0008 \\
\hline lnWage & $-0.335 * * *$ & -0.0015 & $-0.299 * * *$ & -0.0013 & $-0.292 * * *$ & -0.0013 & $-0.227 * * *$ & -0.0010 \\
\hline
\end{tabular}




\begin{tabular}{|c|c|c|c|c|c|c|c|c|}
\hline & $(-7.1)$ & & $(-5.78)$ & & $(-5.67)$ & & $(-2.81)$ & \\
\hline lnAge & $\begin{array}{l}-0.211 \\
(-1.11)\end{array}$ & -0.0010 & $\begin{array}{l}-0.255 \\
(-1.34)\end{array}$ & -0.0011 & $\begin{array}{l}-0.239 \\
(-1.25)\end{array}$ & -0.0010 & $\begin{array}{l}-0.251 \\
(-1.33)\end{array}$ & -0.0011 \\
\hline lnAge2 & $\begin{array}{c}1.412 * * * \\
(16.96)\end{array}$ & 0.0064 & $\begin{array}{c}1.440 * * * \\
(16.96)\end{array}$ & 0.0062 & $\begin{array}{c}1.429 * * * \\
(16.97)\end{array}$ & 0.0062 & $\begin{array}{c}1.433 * * * \\
(17.13)\end{array}$ & 0.0062 \\
\hline Cons & $\begin{array}{c}7.879 * * * \\
(4.91)\end{array}$ & & $\begin{array}{c}7.329 * * * \\
(4.44)\end{array}$ & & $\begin{array}{c}7.164 * * * \\
(4.37)\end{array}$ & & $\begin{array}{c}6.872 * * * \\
(4.1)\end{array}$ & \\
\hline \multicolumn{9}{|c|}{ Wald test for heteroscedasticity. $\mathrm{H}_{0}$ : Insigma2=0 } \\
\hline $\begin{array}{r}\text { Insigma2 } \\
\text { lempl }\end{array}$ & $\begin{array}{c}-0.136 * * * \\
(-6.41)\end{array}$ & & $\begin{array}{c}-0.137 * * * \\
(-6.49)\end{array}$ & & $\begin{array}{c}-0.139 * * * \\
(-6.55)\end{array}$ & & $\begin{array}{c}-0.138 * * * \\
(-6.51)\end{array}$ & \\
\hline $\begin{array}{l}\text { chi2(1) } \\
\text { (Prob>chi2) }\end{array}$ & $\begin{array}{l}41.080 \\
(0.000) \\
\end{array}$ & & $\begin{array}{l}42.130 \\
(0.000) \\
\end{array}$ & & $\begin{array}{l}42.950 \\
(0.000) \\
\end{array}$ & & $\begin{array}{l}42.440 \\
(0.000) \\
\end{array}$ & \\
\hline $\begin{array}{l}\text { Log pseudo- } \\
\text { likelihood }\end{array}$ & -2465.22 & & -2441.221 & & -2444.791 & & -2442.700 & \\
\hline industry dummies & INCL & & INCL & & INCL & & INCL & \\
\hline time dummies & INCL & & INCL & & INCL & & INCL & \\
\hline regional dummies & INCL & & INCL & & INCL & & INCL & \\
\hline ownership dumm. & INCL & & INCL & & INCL & & INCL & \\
\hline $\mathbf{N}$ & 32330 & & 32102 & & 32102 & & 32102 & \\
\hline $\operatorname{Pr}(y=1)$ in sample & & 0.0328 & & 0.0328 & & 0.0328 & & 0.0328 \\
\hline $\begin{array}{l}\operatorname{Pr}(y=1) \text { mean of } \\
\text { model prediction }\end{array}$ & & 0.0327 & & 0.0328 & & 0.0328 & & 0.0328 \\
\hline $\begin{array}{l}\operatorname{Pr}(y=1) \text { predicted } \\
\text { at means }\end{array}$ & & 0.0011 & & 0.0010 & & 0.0010 & & 0.0010 \\
\hline
\end{tabular}

Notes: - t-statistics are in parentheses,

- Huber/White/sandwich estimator of variance

- for dummy variables marginal effect $\mathrm{dP} / \mathrm{dX}$ is for discrete change from 0 to 1

- ***,**,* denotes significance at $1 \%, 5 \%$ and $10 \%$, respectively.

\section{Appendix 2: Random effects probit estimates of exit model for the sub- sample of domestic firms in Slovenian manufacturing sector, 1994-2003}

\begin{tabular}{|l|c|}
\hline & Coefficients \\
\hline \hline MNEentry & $0.922(0.62)$ \\
\hline MNEentry·dTFPlow & $6.061^{* * *}(2.75)$ \\
\hline dTFPlow & $-0.137^{* *}(-2.16)$ \\
\hline entry & $0.184(0.31)$ \\
\hline hFDI & $2.843^{* *}(2)$ \\
\hline hFDI· lnWage & $-0.448^{* *}(-2.16)$ \\
\hline ReghFDI & $0.457(1.07)$ \\
\hline BackFDI & $1.848(0.92)$ \\
\hline BackConc & $-13.734(-0.66)$ \\
\hline ForFDI & $-4.096^{* *}(-1.96)$ \\
\hline ForConc & $5.707(0.31)$ \\
\hline IMint & $0.053(0.24)$ \\
\hline Imint·COMPL & $1.403^{* *}(2.16)$ \\
\hline COMPL & $-0.216(-1.19)$ \\
\hline plants & $-0.109^{* * *}(-3.57)$ \\
\hline HHI & $0.289(1.23)$ \\
\hline
\end{tabular}




\begin{tabular}{|l|c|}
\hline dexport & $-0.016(-0.31)$ \\
\hline dexmajor & $0.172 * *(2.13)$ \\
\hline dprofit & $-0.379 * * *(-5.48)$ \\
\hline InEmpl & $-0.841 * * *(-12.99)$ \\
\hline InEmpl2 & $0.024(1.35)$ \\
\hline InTFP & $-0.282^{* * *}(-4.89)$ \\
\hline InKint & $-0.229 * * *(-8.47)$ \\
\hline InWage & $-0.327 * * *(-6.55)$ \\
\hline InAge & $-0.285(-1.22)$ \\
\hline InAge2 & $1.583 * * *(18.8)$ \\
\hline \hline Likelihood-ratio test of rho=0 \\
\hline chibar2(01) & $0(\sim 1.000)$ \\
\hline pseudo R2 & 0.47 \\
\hline Log pseudo-likelihood & -2477.0479 \\
\hline industry dummies & INCL \\
\hline time dummies & INCL \\
\hline regional dummies & INCL \\
\hline ownership dummies & INCL \\
\hline N & 32227 \\
\hline \hline
\end{tabular}

Notes: - t-statistics are in parentheses,

- ***, $* *, *$ denotes significance at $1 \%, 5 \%$ and $10 \%$, respectively. 


\section{DAVIDSON INSTITUTE WORKING PAPER SERIES - Most Recent Papers}

The entire Working Paper Series may be downloaded free of charge at: www.wdi.umich.edu

CURRENT AS OF 10/11/06

\begin{tabular}{|c|c|c|}
\hline Publication & Authors & Date \\
\hline $\begin{array}{l}\text { No. 841: The Role of Foreign Direct Investment in the Firm Selection } \\
\text { Process in a Host Country: Evidence from Slovenia }\end{array}$ & Katja Zajc Kejzar & Sept 2006 \\
\hline $\begin{array}{c}\text { No. 840: Family Ownership and Control in Large Firms: The Good, The } \\
\text { Bad, The Irrelevant - and Why? }\end{array}$ & Mike Peng and Yi Jiang & Oct 2006 \\
\hline No. 839: Price Linkages of Russian Regional Markets & Konstantin Gluschenko & Sept 2006 \\
\hline $\begin{array}{l}\text { No. 838: The Effect of Pre-Primary Education on Primary School } \\
\text { Performance }\end{array}$ & $\begin{array}{l}\text { Samuel Berlinski, Sebastian } \\
\text { Galiani and Paul Gertler }\end{array}$ & July 2006 \\
\hline $\begin{array}{l}\text { No. 837: Do Investors Value Insider Trading Laws? International } \\
\text { Evidence }\end{array}$ & Laura Beny & Aug 2006 \\
\hline No. 836: How corruption Hits People When They Are Down & Jennifer Hunt & Aug 2006 \\
\hline No. 835: Mirage at the Bottom of the Pyramid & Aneel Karnani & Aug 2006 \\
\hline $\begin{array}{l}\text { No. 834: Ownership concentration and firm performance: Evidence from } \\
\text { an emerging market }\end{array}$ & Irena Grosfeld & June 2006 \\
\hline $\begin{array}{l}\text { No. 833: Institutions, Networks and Entrepreneurship Development in } \\
\text { Russia: An Exploration }\end{array}$ & Ruta Aidis and Saul Estrin & June 2006 \\
\hline $\begin{array}{l}\text { No. 832: Long \& Short Run Linkages in CEE Stock Markets: } \\
\text { Implications for Portfolio Diversification \& Stock Market Integration }\end{array}$ & $\begin{array}{l}\text { Manolis Syllignakis and Georgios } \\
\text { Kouretas }\end{array}$ & July 2006 \\
\hline $\begin{array}{l}\text { No. 831: Inequality, Fiscal Capacity and the Political Regime } \\
\text { Lessons from the Post-Communist Transition }\end{array}$ & $\begin{array}{l}\text { Christopher J. Gerry and Tomasz } \\
\text { Mickiewicz }\end{array}$ & July 2006 \\
\hline $\begin{array}{l}\text { No. 830: Business Groups in Emerging Markets - } \\
\text { Financial Control and Sequential Investment }\end{array}$ & Christa Hainz & June 2006 \\
\hline $\begin{array}{l}\text { No. 829: Sophisticated Discipline in Nascent Deposit Markets: Evidence } \\
\text { from Post-Communist Russia }\end{array}$ & $\begin{array}{l}\text { Alexei Karas, William Pyle and } \\
\text { Koen Schoors }\end{array}$ & June 2006 \\
\hline $\begin{array}{l}\text { No. 828: Financial Deregulation and Financial Development, and } \\
\text { Subsequent Impact on Economic Growth in the CzechRepublic, Hungary } \\
\text { and Poland }\end{array}$ & Patricia McGrath & June 2006 \\
\hline $\begin{array}{l}\text { No. 827: The Determinants \& Excessiveness of Current AccountDeficits } \\
\text { in Eastern Europe \& the Former Soviet Union }\end{array}$ & Aleksander Aristovnik & June 2006 \\
\hline $\begin{array}{l}\text { No. 826: Privatization with Government Control: Evidence from the } \\
\text { Russian Oil Sector }\end{array}$ & $\begin{array}{l}\text { Daniel Berkowitz and Yadviga } \\
\text { Semikolenova }\end{array}$ & $\begin{array}{l}\text { February } \\
2006\end{array}$ \\
\hline No. 825: Corruption \& Bureaucratic Structure in a Developing Economy & John Bennett and Saul Estrin & $\begin{array}{l}\text { February } \\
2006\end{array}$ \\
\hline No. 824: Regulatory Barriers \& Entry in Developing Economies & John Bennett and Saul Estrin & $\begin{array}{c}\text { March } \\
2006\end{array}$ \\
\hline No. 823: Enterprise Restructuring in Belarus & $\begin{array}{l}\text { Marina Bakanova, Saul Estrin, } \\
\text { Igor Pelipas and Sergei Pukovic }\end{array}$ & May 2006 \\
\hline $\begin{array}{l}\text { No. 822: Reforms, Entry and Productivity: Some Evidence from the } \\
\text { Indian Manufacturing Sector }\end{array}$ & $\begin{array}{l}\text { Sumon Kumar Bhaumik, } \\
\text { Shubhashis Gangopadhyay and } \\
\text { Shagun Krishnan }\end{array}$ & $\begin{array}{l}\text { March } \\
2006\end{array}$ \\
\hline $\begin{array}{l}\text { No. 821: Falling Walls and Lifting Curtains: Analysis of Border Effects } \\
\text { in Transition Countries }\end{array}$ & Yener Kandogan & $\begin{array}{c}\text { March } \\
2006\end{array}$ \\
\hline $\begin{array}{l}\text { No. 820: Home versus Host Country Effects of FDI: Searching for New } \\
\text { Evidence of Productivity Spillovers }\end{array}$ & Priit Vahter and Jaan Masso & $\begin{array}{l}\text { March } \\
2006\end{array}$ \\
\hline $\begin{array}{l}\text { No. 819: Earnings Inequality in India: Has the Rise of Caste and } \\
\text { Religion Based Politics in India had an Impact? }\end{array}$ & $\begin{array}{l}\text { Kumar S. Bhaumik and Manisha } \\
\text { Chakrabarty }\end{array}$ & $\begin{array}{l}\text { March } \\
2006\end{array}$ \\
\hline
\end{tabular}

